KATHARINE STOVE

\title{
DEFINING A RIGHT OF REPLY: AN EXAMINATION OF THE LAW COMMISSION'S PROPOSALS TO USE A RIGHT OF REPLY TO REGULATE ONLINE CONDUCT
}

\section{LLM RESEARCH PAPER}

(Submitted for the LLB(Hons) Degree)

LAWS 524: HUMAN RIGHTS

FACULTY OF LAW

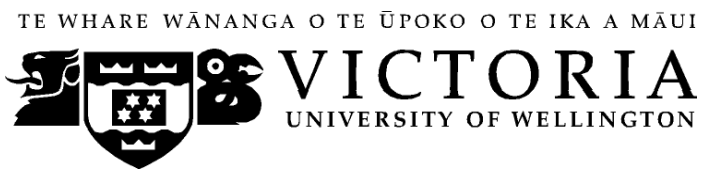

2013 


\section{Contents}

I Introduction

II The Law Commission's Proposals (as adopted by Cabinet's Social Policy Committee)

III The Nature of the Internet: Is a Right of Reply is Suitable in an Online Context?

A Borderlessness and Potential Audience Sizes

B The "Streisand Effect" and the Ease of Redistribution

C The Permanent Nature of Online Information

D A "Built in" Right of Reply

E Conclusion

IV Should a Right of Reply Extend Beyond the Media to Ordinary Citizens?

$V$ How a Right of Reply Infringes Freedom of Expression
A Self-Fulfillment
B The Importance of Discovering Truth
C Participation in Democracy
D Conclusion

VI Balancing Freedom of Expression and Protection of Reputation: What is the Best Form of a Right of Reply?

(a) does the limiting measure serve a purpose sufficiently important to justify curtailment of the right or freedom?

1 Purpose of a right of reply

2 Rights to reputation

3 Conclusion on the rationales for protecting reputation

(b) Proportionality:

(i) is the limiting measure rationally connected with its purpose?

1 How does a right of reply protect reputation?

2 Why a right of reply should extend beyond remedying false allegations that harm reputation

3 Conclusion on rational connection

(ii) does the limiting measure impair the right or freedom no more than is reasonably necessary for sufficient achievement of its purpose?

1 When a right of reply should be used

2 What form a right of reply should take

3 Summary of when and how a right of reply should be used

4 Other available remedies

5 Conclusion on minimal impairment

(iii) is the limit in due proportion to the importance of the objective?

1 How a right of reply advances free speech rationales

2 The value of speech

3 Applying the proportional limb

VII Conclusion

VIII Bibliography 


\begin{abstract}
This paper examines the Law Commission's proposals to use a right of reply as a remedy within a new regime to combat harmful digital communications on the Internet in its Ministerial Briefing Paper, Harmful Digital Communications: The Adequacy of Current Sanctions and Remedies. It seeks to determine whether a right of reply is a suitable tool to use in an online context against ordinary citizens, when it has typically been an offline remedy for use against the media. It also considers the best form for a right of reply under this new regulatory regime, in order for it to constitute a proportional limit on a defendant's right to freedom of expression. It concludes that a right of reply could be a suitable remedy under the regime, and it could constitute a proportional limit on a defendant's freedom of expression, but a Court should carefully balance the harms a right of reply might pose against the values of free speech implicated in each circumstance, on a case-by-case basis, in order to ensure the limitations a right of reply might pose on freedom of expression are always proportional and justified.
\end{abstract}

\title{
Word length
}

The text of this paper (excluding abstract, table of contents, footnotes and bibliography) comprises approximately 14, 994 words.

\section{Subjects and Topics}

Torts - Defamation - Rights of reply

Internet Regulation

Reputation

Freedom of Expression

New Zealand Bill of Rights Act 1990 - section 5 - Balancing Rights and

Interests $-R v$ Oakes $-R v$ Hansen 


\section{Introduction}

In response to growing concern over the use of new technologies to cause harm, last year the Law Commission ("the Commission") proposed a number of recommendations to regulate online conduct in its Ministerial Briefing Paper, Harmful Digital Communications: The Adequacy of Current Sanctions and Remedies. ${ }^{1}$ There is concern that the Internet has become something akin to "a vast unsupervised playground" where people are free to harass and defame others with little to no repercussions. ${ }^{2}$ The Commission's paper considered how to adapt New Zealand's law to the digital age, make the law easier for the ordinary citizen to understand, and provide meaningful remedies for significant harm caused by digital communications. ${ }^{3}$ Earlier this year, Cabinet's Social Policy Committee endorsed most of the Commission's proposals. ${ }^{4}$ Many of the proposals require legislative reform in order to be implemented, and so a Bill is intended to be passed by the end of $2013 .{ }^{5}$ The Commission has proposed that a right of reply should be available to a complainant to remedy a harmful digital communication. ${ }^{6}$ However, neither the Commission nor the Social Policy Committee have provided any guidance as to the scope or availability of this remedy, although it has been noted that a Court should give regard to freedom of expression when considering remedies. ${ }^{7}$ This paper addresses when and how a right of reply should be used under this new regime in order for it to constitute a justified limitation on a defendant's right to freedom of expression.

There is no right of reply in New Zealand's current law that a right of reply under this new regime can model itself on, although the Broadcasting Standards Authority does have the ability to grant a similar remedy; it can order the publication of a general

\footnotetext{
${ }^{1}$ Law Commission Harmful Digital Communications: The Adequacy of Current Sanctions and Remedies (NZLC Ministerial Briefing Paper, 2012).

${ }^{2}$ At 5.

3 At 6.

${ }^{4}$ Cabinet Social Policy Committee Harmful Digital Communications: Cabinet Social Policy Cabinet Social Policy Committee <http://www.justice.govt.nz/publications/global-publications/h/harmfuldigital-communications-cabinet-social-policy-Cabinet Social Policy Committee/publication>

5 At [111].

${ }^{6}$ Law Commission, above n 1, at [5.66].

${ }^{7}$ At $[5.80]$.
} 
statement which could include a "reply" from a complainant. ${ }^{8}$ Although there is a "right of reply" provision in the Defamation Act $1992,{ }^{9}$ it is seen as dissatisfactory and ineffective; ${ }^{10}$ it does not prevent a claimant from instigating defamation proceedings and a defendant can easily refuse to publish the reply, ${ }^{11}$ so it is seldom used, and consequently of little help to this paper. Instead, this paper draws inspiration from other jurisdictions to consider what form a right of reply should take under this new regime in order to impose a reasonable and demonstrably justified limit on a defendant's freedom of expression.

A right of reply traditionally refers to the right of a citizen to have a newspaper publish his side of the story when that newspaper has published a defamatory statement about them, ${ }^{12}$ or affected their right to personality. ${ }^{13}$ The purpose of defamation laws have typically been to help protect a claimant's reputation. ${ }^{14}$ Since New Zealand has no general right to personality, ${ }^{15}$ but has adopted defamation laws, this paper proceeds on the assumption that a right of reply under the new regime is also intended to protect reputation in a similar way to defamation law.

Part II of this paper gives a brief outline of the Commission's recommendations for this new regime for regulating online conduct before addressing the following issues. Since a right of reply has traditionally been used against the media in an offline context, Part III explains why a right of reply is a suitable remedy in an online context, while Part IV examines why it should be made available against ordinary citizens and not just against media defendants. Part $\mathrm{V}$ details how a right of reply might breach a defendant's right to freedom of expression, whilst Part VI moves on to consider when

\footnotetext{
${ }^{8}$ Broadcasting Act 1989, s 13(1).

${ }^{9}$ Section 25.

${ }^{10}$ Tracey Walker Reputation Matters: A Practical Legal Guide to Managing Reputational Risk (CCH New Zealand Limited, Auckland, 2012) at 33.

${ }^{11}$ Section 25.

${ }^{12}$ Richard C Donnelly "A Right of Reply: An Alternative to an Action for Libel” (1948) 34 Va Law Rev 867 at $884-885$.

${ }^{13}$ Georgios Gounalakis Privacy and the Media: A Comparative Perspective (Verlag CH Beck, Munchen, 2000) at 57-69. See also: Kyu Ho Youm "The Right of Reply and Freedom of the Press: An International and Comparative Perspective" (2008) 76 Geo Wash L Rev 1017 at 1042.

${ }^{14}$ Lawrence McNamara Defamation and Reputation (Oxford University Press, New York, 2007), at 92. See also: Lange v Atkinson and Australian Consolidated Press NZ Ltd [1997] 2 NZLR 22 (HC) at 30 and Television New Zealand Ltd v Quinn [1996] 3 NZLR 24 (CA) at 37-38.

${ }^{15}$ Huw Beverley-Smith, Ansgar Ohly and Agnes Lucas-Schloetter Privacy, Property and Personality: Civil Law Perspectives on Commercial Appropriation (Cambridge University Press, New York, 2005) at 207
} 
and how a right of reply should be used in order for this limit to be demonstrably justified according to section 5 of the New Zealand Bill of Rights Act (NZBORA). This paper ultimately concludes that a right of reply could constitute a justified limitation on free speech, but this will essentially depend on the nature of the original statement and how the benefits of a right of reply weigh up against the limits imposed on the free speech values implicated in each particular case. Whether or not a right of reply is overall a proportionate and justified infringement of free speech should therefore be determined by the courts on a case by case basis.

\section{The Law Commission's Proposals (as adopted by Cabinet's Social Policy Committee)}

The Commission has proposed the adoption of statutory principles derived from $\mathrm{New}$ Zealand law, the breach of which would entitle a person to seek redress. ${ }^{16}$ The principles are as follows: ${ }^{17}$

There should be no [digital] communications which cause significant emotional distress to an individual because they:

1. Disclose sensitive personal facts about individuals.

2. Are threatening, intimidating or menacing.

3. Are grossly offensive.

4. Are indecent or obscene.

5. Are part of a pattern of conduct which constitutes harassment.

6. Make false allegations.

7. Contain matter which is published in breach of confidence.

8. Incite others to send messages to a person with the intention of causing that person harm.

9. Incite or encourage another to commit suicide.

10. Denigrate a person by reason of that person's colour; race; ethnic or national origins; religion; ethical belief; gender; sexual orientation or disability.

The principles are derived from several aspects of New Zealand domestic law and are in a sense "stripped down law". ${ }^{18}$ Once a principle has been breached, a claimant's

\footnotetext{
${ }^{16}$ Law Commission, above $\mathrm{n} 1$, at [5.66].

17 At [5.66].
} 
first point of call would be an agency approved by the Ministry ("approved agency"). ${ }^{19}$ The approved agency would receive initial complaints about digital communications, investigate them and liase with website hosts and Internet Service Providers (ISPs) to negotiate causes of action to deal with the harm without the need for court action. ${ }^{20}$

If the approved agency does not provide the claimant with adequate redress, and the complaint is sufficiently serious, the matter can be dealt with by the District Court. ${ }^{21}$ The Commission originally proposed a new tribunal to deal with such complaints, but this suggestion was rejected by the Social Policy Committee. ${ }^{22}$ The Commission suggested a number of remedies be available to the tribunal that the Committee decided should instead be available to the District Court. ${ }^{23}$ These include the power to issue: $^{24}$

1. An order to takedown material - issued against either the perpetrator or the ISP.

2. An order that the defendant cease the conduct in question.

3. An order not to encourage others to engage in similar communications with the complainant.

4. A direction that the order may apply to other persons if there is evidence that they have been encouraged to engage in harmful communications.

5. A declaration that the communication breaches the statutory principles.

6. An order requiring publication of a correction.

7. An order that a right of reply to be given to the complainant.

8. An order requiring publication of an apology.

9. An order that the identity of an anonymous communication be released.

10. An order that the names of any parties be suppressed.

The Commission intends to enable these orders to be imposed against the original communicator of the harmful statement, or website hosts, ISPs and Internet intermediaries. ${ }^{25}$ This paper focusses on the availability of a right of reply against the

\footnotetext{
${ }^{18}$ Law Commission, above $\mathrm{n}$ 1, at [5.63].

${ }^{19}$ At [5.45].

${ }^{20}$ Cabinet Social Policy Committee, above n 4, at [40.1]-[40.9].

${ }^{21}$ At [5].

${ }^{22}$ At [45]-[49].

${ }^{23}$ At [55].

${ }^{24}$ At [55.1]-[55.10].

${ }^{25}$ Law Commission, above $\mathrm{n} 1$, at [5.87].
} 
original communicator, as issues regarding ISP and hosting liabilities are beyond the scope of this paper.

In a separate report published this year, The News Media Meets New Media: Rights, Responsibilities and Regulation in the Digital Age, the Commission proposed a new independent media standards authority to replace the Press Council, the Broadcasting Standards Authority and the Online Standards Authority. ${ }^{26}$ However, these proposals have been rejected by the government. ${ }^{27}$ This new body was to be called the New Media Standards Authority (NMSA). ${ }^{28}$ The goal of the NMSA was to apply consistent reporting standards across print, broadcasting and online media. ${ }^{29}$ The NMSA was to provide quick remedies for breaches of standards by the media, and would also have the power to grant an order for a right of reply. ${ }^{30}$ In order to be a member of the NMSA, a person would have had to regularly publish information, a significant amount of which involves the generation and dissemination of news to a public audience, and choose to be held accountable to the NMSA. ${ }^{31}$ The Commission noted that though many media-like individuals may choose not to be held accountable NMSA, they would still be covered by the recommendations outlined in the earlier Ministerial Briefing Paper for the regulation of online conduct. ${ }^{32}$ Thus, it would appear that the Commission originally envisaged a right of reply be made available against both the "media" and the ordinary citizen using the Internet. This paper focuses on the Commission's proposals for regulating online conduct of ordinary citizens, because these proposals have not been rejected, and it is important to consider whether a right of reply is a suitable remedy against an ordinary citizen, as traditionally a right of reply has only been available against the media. ${ }^{33}$

\footnotetext{
${ }^{26}$ Law Commission The News Media Meets 'New Media': Rights, Responsibilities and Regulation in the Digital Age (NZLC R128, 2013) at 10.

27 Judith Collins and Craig Foss "Government responds to news media report" (12 September 2013) beehive.govt.nz <http://beehive.govt.nz/release/government-responds-news-mediareport?utm_source $=$ feedburner\&utm_medium $=$ email\&utm_campaign $=$ Feed $\% 3 \mathrm{~A}+$ beehive-govtnz\%2Fportfolio\%2Fjustice+\%28Justice+-+beehive.govt.nz\%29>

${ }^{28}$ Law Commission, above $\mathrm{n} 26$, at 11.

${ }^{29}$ At 5 .

${ }^{30}$ At 12 .

${ }^{31}$ At 12 .

${ }^{32}$ At 14 .

${ }^{33}$ Donnelly, above n 12 , at $884-885$.
} 
III The Nature of the Internet: Is a Right of Reply is Suitable in an Online Context?

\section{A Borderlessness and Potential Audience Sizes}

The Internet allows for broad, "borderless" communications; it knows no geographical boundaries. ${ }^{34}$ Moreover, online communications, such as blogs and forums, allow for one-to-many publications; we are no longer limited to one-to-one publications, such as fax and email. ${ }^{35}$ The combination of "borderlessness" and the capacity to allow one-to-many communications makes online communications virtually uncontrollable, ${ }^{36}$ as there is often no way to restrict the audience size and readership. It is thus difficult to conceive how many readers a publication will actually generate. As of October 2011, there were approximately 3.6 million Internet connections in New Zealand $;{ }^{37}$ most of the population can now boast access to the Internet. Since the Internet is now widely used, the potential audience size can be immeasurable in comparison to how many might read similar article in a newspaper. ${ }^{38}$ The potential damage of statements on the Internet is a lot higher than offline statements, giving greater urgency to the need of a remedy.

\section{$B$ The "Streisand Effect" and the Ease of Redistribution}

Things on the Internet happen quickly, and in unpredictable ways ${ }^{39}$ the viral nature of the Internet can exacerbate the harms of an original defamatory statement by increasing the number of potential readers through redistribution. ${ }^{40}$ Seeking the removal of something can often lead to further publicity, adding fuel to the fire. ${ }^{41}$ This is often referred to as the "Streisand Effect", after Barbara Streisand brought a lawsuit against a photographer to get a photo of the front of her house taken off his website. ${ }^{42}$

\footnotetext{
${ }^{34}$ Dan Jerker B Svantesson Private International Law and The Internet (Kluwer Law International BV, The Netherlands, 2007) at 34-35.

${ }^{35}$ At 34.

${ }^{36}$ Svantesson, above n 34, at 35.

${ }^{37}$ Law Commission The News Media Meets 'New Media': Rights, Responsibilities and Regulation in the Digital Age (NZLC IP27, 2011) at 1.8.

${ }^{38}$ Svantesson, above n 34, 36-37.

${ }^{39}$ Mike Wagner "Privacy and Reputaiton in the Internet Age" (2013) 71 Advocate at 347 at 351.

${ }^{40}$ Law Commission, above n 1, at [2.42].

${ }^{41}$ Wagner, above $\mathrm{n} 39$, at 351 .

${ }^{42}$ At 355.
} 
The lawsuit generated publicity, and the photo started getting copied to other webpages, making its removal from the web pretty much impossible. ${ }^{43}$ When people are told they should not see something, this often makes them want to see it more. ${ }^{44}$ There is a culture of anti-censorship on the Internet, particularly among younger users, ${ }^{45}$ and when people feel there is a danger of something being censored, or restricted, many feel obliged to personally make sure the information remains available. ${ }^{46}$ Redistribution is very easy online, once a person possesses a file, the information can be quickly copied at little or no cost to the redistributors. ${ }^{47}$ A right of reply may result in less uproar and less publicity or dissemination of an offending statement than outright censorship or restriction.

\section{$C$ The Permanent Nature of Online Information}

Search engines can further expose statements that at first had very limited exposure when originally posted. ${ }^{48}$ The permanent nature of digital information can lead to the re-victimisation of a person long after an original statement was made. ${ }^{49}$ For example, employers may do a quick Google search of a prospective employee, unearthing statements made about them years ago, and this could result in a decision not to hire that person. ${ }^{50}$ In an online context, today's news is not necessarily tomorrow's fish and chip wrapper. Rightly or wrongly, the Internet is making it harder for people to escape their past. A right of reply can ensure that, should someone conduct an Internet search on an individual years after a damaging statement was made about them, that statement will be put into context or at least balanced out by the individual's side of the story.

\footnotetext{
${ }^{43}$ Wagner, above n 39, at 355.

44 Jessica Medberry "Censorship and Adolescent Literature" (Senior Honors Thesis, Colorado State University, 15 December 2009) at 36 and 49-50.

${ }^{45}$ Ruth Rettie "Net Generation Culture" (2002) 3 JECR 254 at 257. See also: Daniel W Drezner "The Global Governance of the Internet: Bringing the State Back In" (2004) 119 Polit Sci Q 477 at 488.

${ }^{46}$ Eduard Kovaks "Anonymous Hackers Plan Anti-Facebook Censorship Protest for April 6" (26 March 2013) Softpedia <http://news.softpedia.com/news/Anonymous-Hackers-Plan-Anti-FacebookCensorship-Protest-for-April-6-340389.shtml>

See also: Emma Woolacott "As Pirate Bay Launches Anti-Censorship Browser, Has It Lost Its Way?" (12 August 2013) Forbes <http://www.forbes.com/sites/emmawoollacott/2013/08/12/as-pirate-baylaunches-anti-censorship-browser-has-it-lost-its-way/>

47 Svantesson, above n 34, at 36.

${ }^{48}$ Law Commission, above $\mathrm{n} 1$, at [3.70] and [3.87].

49 At [2.42].

${ }^{50}$ Erik P Lewis, “Unmasking 'Anon12345': applying an appropriate standard when private citizens seek the identity of anonymous internet defamation defendants" (2009) 2009 U Ill L Rev 947 at 948.
} 


\section{A "Built in" Right of Reply}

The Internet has given new meaning to "freedom of expression" by allowing the ordinary citizen to "seek, receive and impart information" in unprecedented ways. ${ }^{51}$ Anyone can publish anything on the Internet, often anonymously. ${ }^{52}$ You no longer need a lot of technical knowledge or financial capabilities to publish information to a wide audience. ${ }^{53}$ The public have been given the tools to edit and publish whatever they like on the Web. ${ }^{54}$ Some commentators argue that this means it is unnecessary and potentially damaging to subject the "vibrant discussion medium" that is the Internet, to "a bureaucratic model of statement and counterstatement" that is a right of reply. ${ }^{55}$ Because virtually anyone can now publish anything they want on the Internet, there are some people of the view that this means a right of reply is therefore unnecessary in the context of the Internet. ${ }^{56}$ In other words, some commentators believe that there is no reason to allow the state to force a publisher to publish a reply when a complainant could publish their own reply somewhere else on the Web.

On the other hand, other commentators are of the view that, "The right of reply is a particularly appropriate remedy in the online environment because it allows for an instant response to contested information and it is technically easy to attach the replies from the persons affected. "57 The right of reply is already encoded within the framework of the unregulated Internet; it essentially has a "built in right of reply". ${ }^{58}$ This would make a right of reply very simple to use, and there are virtually no publishing costs.

\footnotetext{
${ }^{51}$ Law Commission, above n 26, at [1.3].

52 Wagner, above n 39 , at 350 .

${ }^{53}$ Svantesson, above n 34, at 35.

${ }^{54}$ Law Commission, above $\mathrm{n} 1$, at [3.19].

${ }^{55}$ Graham J H Smith and Bird and Bird Internet Law and Regulaton (4th ed, Sweet \& Maxwell, London, 2007) at 345.

${ }^{56}$ At 345-346.

57 Proposal for a Recommendation of the European Parliament and of the Council on the protection of minors and human dignity and on the right of reply in relation to the competitiveness of the European audiovisual and online information services industry, 7064/06 (March 2006) at 13

58 Judit Bayer "Liability of ISPs for Third Party Content" (Senior Research Fellow Paper, Victoria University of Wellington, 2006) at 22.
} 
There is also some doubt as to whether the Internet truly does level the playing field between the average citizen and the mass media. ${ }^{59}$ Richard McChesney argues that, while the Internet is revolutionary, it has not revolutionised power structures. ${ }^{60}$ Indeed, a reader will probably be more inclined to believe what has been posted on a news website, rather than a response from an individual blogger, and very few individuals can direct as much viewer traffic to their sites as corporations can. ${ }^{61}$ Moreover, a person who has been personally targeted by a blog post may be able to post his own response in a comment on the post, but "a single correcting comment embedded in a long tail of abusive commentary may not have much effect." ${ }^{62}$ Therefore, in some cases, a self-administered reply to a damaging statement may not effectively negate the harm of the original statement. A self-administered reply may end up buried under thousands of defamatory comments, or perhaps not taken seriously in the face of the authority of the original speaker. In such cases, a Court may need to step in to make sure that a reply negates the harm of the statement. The Commission states in its Ministerial Briefing Paper that where self-regulatory systems and tools on the Internet are unavailable or ineffective, then a person who has suffered serious harm should have access to redress. ${ }^{63}$ This suggests that a court sanctioned right of reply should only be available where a person was unable to post their own adequate reply to the defamatory statement.

\section{E Conclusion}

Due to the fact that a publication can reach a much larger audience, both because of the nature of the Internet and the ease of redistribution, the potential for damage to reputation is much greater online than offline. The permanent nature of online information means that harm is more likely to keep reoccurring. The anti-censorship sentiments and the ease of publication on the Internet mean that a right of reply is a more suitable remedy than a takedown. The fact that anyone can publish almost anything they want on the Internet does not mean that a court-ordered reply is

\footnotetext{
${ }^{59}$ Jerome A Barron "Rights of Access and Reply to the Media in the United States Today" (2003) 25 Comm \& L 1 at 11.

${ }^{60}$ Richard McChesney Rich Media, Poor Democracy: Communications Politics in Dubious Times (University of Illinois Press, Illinois, 1999) at 182-183.

${ }^{61}$ Svantesson, above $\mathrm{n} 34$, at 36.

${ }^{62}$ Law Commission, above $\mathrm{n} 1$, at [3.68].

${ }^{63}$ At [1.39].
} 
unnecessary due to the power imbalances that exist in online communities. Therefore, this paper proceeds on the assumption that a right of reply is a suitable remedy in an online context.

\section{Should a Right of Reply Extend Beyond the Media to Ordinary Citizens?}

The concept of a right of reply was devised at a time when publication rights were at the hands of a powerful few, whereas now on the Internet, anyone can be a publisher. ${ }^{64}$ By drawing a distinction between regimes for the "new media" and the ordinary citizen and then allowing a right of reply to be used under both regimes, the Commission perhaps did not intend for the right of reply to extend solely to the media. However, given the lack of direction from the Commission with regards to remedies under the new regime, the courts might nevertheless decide that a right of reply is better suited to "media-like" defendants.

At the European Union level, the European Parliament has adopted a recommendation including the right of reply in relation to European audiovisual and online information services, but this right is only enforceable against defendants considered to be a part of the "media". ${ }^{65}$ The question is whether this new regime should follow suit and only allow a right of reply in cases where the defendant is a member of the media. The issue then becomes, "what constitutes the media in an online environment?" Does an individual blogger count alongside a newspaper's website?

The distinction between the media and the ordinary citizen has become blurred. The mainstream media has begun to harness the power of online social media by using user-generated content to distribute and promote their own content. ${ }^{66}$ As a result, there has been a convergence between the mainstream media and the "new media" made up of ordinary citizens. ${ }^{67}$ Mainstream news webpages get a hold of breaking news stories from individual bloggers, and source commentary from Facebook pages

\footnotetext{
${ }^{64}$ Smith and Bird and Bird, above n 55, at 345-346.

${ }^{65}$ EDRI-gram French Draft Decree Regarding The Right To Reply On The Internet

(28 March 2007) EDRI-gram < http://www.edri.org/edrigram/number5.6/right-to-reply-france>

${ }^{66}$ Law Commission, above n 26, at [1.4].

${ }^{67}$ Law Commission, above n 26, at [1.5].
} 
and Twitter accounts. ${ }^{68}$ The Council of Europe's 2004 Recommendation pertaining to rights of reply on the Internet only allows replies to the media, or any dissemination of "edited information". ${ }^{69}$ There is some ambiguity as to what "edited" means. For example, whether it means edited by someone other than the author. ${ }^{70}$ In which case, should a right of reply extend to the ordinary blogger or moderated discussion forums?" "Edited information" is a broad term that could potentially cover a lot more than what is traditionally considered the "media", so although the Council of Europe has chosen to confine a right of reply to the media, practically it may be more broadly applicable than that.

According to the Commission, to be a part of the "media", a person should regularly publish information, a significant amount of which involves the generation and dissemination of news to a public audience, and choose to define themselves as the "media" by being held accountable to an authority that regulates the media. ${ }^{72}$ The distinction between the media and the ordinary citizen could therefore be the regularity of publication and the nature of the information being published. However, this definition can extend to ordinary citizens that blog or comment on the news, and would not traditionally be considered a part of the media. The only real defining feature of the Commission's test is the voluntary association with a regulatory body, which is not currently possible under New Zealand law given the government's refusal to establish the NMSA.

A right of reply traditionally only applied to the media to address the power imbalances between the media and the ordinary citizen. ${ }^{73}$ One does not need to fall under the above definition of the "media" to pose a power imbalance on the Internet; just because a person does not regularly post about the news does not mean that blogger has no influence in online communities or generates less readership. For example, a regularly frequented forum filled with user-generated content could, in

\footnotetext{
${ }^{68}$ At [1.5].

${ }^{69}$ Smith and Bird and Bird, above n 55, at 345.

${ }^{70}$ At 345.

${ }^{71}$ At 345-346.

${ }^{72}$ Law Commission, above n 26, at 12.

${ }^{73}$ Donnelly, above n 12, at 884. See also: Susana N Vittadini Andres "First Amendment influence in argentine republic law and jurisprudence" (1999) 4 Comm L \& Pol'y 149 at 170. See also Jerome A Barron "Access to the Media - A Contemporary Appraisal" (2006) 35 Hofstra L Rev 937 at 942 and 945.
} 
some cases, be considered a sort of community. A particularly well-respected individual might post about another user in a way that that harms their reputation. Affected users may find it difficult to defend themselves on the forum with their own comments, as other readers are probably more likely to trust the writer that has generated their respect, and a reply may end up buried amongst other abusive comments. The point is power imbalances still exist online out of a traditional media context.

This paper submits that it will be acceptable to order a right of reply even if the defendant is not a member of what is considered to be the "media", as there is no longer a clear distinction between who belongs to the media and who does not; the distinctions provided by the Commission and the Council of Europe are too arbitrary.

\section{$V$ How a Right of Reply Infringes Freedom of Expression}

According to section 14 of the NZBORA, "Everyone has the right to freedom of expression, including the freedom to seek, receive, and impart information and opinions of any kind in any form." All pieces of legislation are to be interpreted as consistently with the NZBORA as possible, ${ }^{74}$ but limits on rights are permissible so long as they are demonstrably justified in a free and democratic society. ${ }^{75}$ One should take a purposive approach to interpreting rights, taking into account the values that underlie them, before moving on to consider whether they have been limited and whether the justifications for limiting them are demonstrably justified. ${ }^{76}$

The New Zealand Court of Appeal has, in Moonen v Film and Literature Board of Review, defined freedom of expression as, "as wide as the human imagination". ${ }^{77}$ An

\footnotetext{
${ }^{74}$ New Zealand Bill of Rights Act 1990, s 6.

${ }^{75}$ Section 5.

${ }^{76}$ Ministry of Transport v Noort [1992] 3 NZLR 260 (CA) at 279 per Richardson J. See also: Claudia Geiringer and Steven Price "Moving From Self-Justification to Demonstrable Justification - the Bill of Rights and the Broadcasting Standards Authority" in Jeremy Finn and Steven Todd (eds) Law, Liberty, Legislation: Essays in Honour of John Butler QC (LexisNexis NZ, Wellington, 2008) at 320. See also: Paul Rishworth "How to Interpret and Apply the Bill of Rights" (paper presented to the New Zealand Law Society The Bill of Rights - Getting the Basics Right Seminar, November 2001) at 7-11.

${ }^{77}$ Moonen v Film and Literature Board of Review [2000] 2 NZLR 9 (CA) at [19] per Tipping J.
} 
'expression' can be "anything attempting to convey some view or purpose". ${ }^{78}$ The Canadian Supreme Court has also held that: ${ }^{79}$

There is no denying that freedom of expression necessarily entails the right to say nothing or the right not to say certain things. Silence is in itself a form of expression which in some circumstances can express something more clearly than words could do.

In West Virginia State Board of Education v Barnette (Barnette), ${ }^{80}$ the United States (US) Supreme Court held that forcing students to recite the Pledge of Allegiance was a violation of their right to free speech guaranteed under the First Amendment of the American Constitution. ${ }^{81}$ This case was the first in the US to rule that forced speech could be an impingement on a person's First Amendment right. ${ }^{82}$ While Barnette involved statements of "sentiment" and "opinion", later cases have relied on it to prevent coercion to disclose more factual information. ${ }^{83}$ For example, the Court in Riley $v$ National Federation of the Blind held that, by requiring professional fundraisers to disclose to potential donors the gross percentage of revenues retained in prior charitable solicitations, the North Carolina Charitable Solicitations Act constituted a breach of the First Amendment. ${ }^{84}$

Therefore, it is reasonable to assume that the New Zealand courts would consider freedom of expression to include a right to silence, or a right to choose what or what not to express, so forcing a defendant to publish a reply presumably infringes free speech. This section considers the main rationales that underpin freedom of expression in order to explain why it is protected and further examine how a right of reply might restrict free speech.

There are three main underlying rationales for the protection of free speech: ${ }^{85}$

\footnotetext{
${ }^{78}$ Thompson v Police [2013] 1 NZLR 848 at [76].

${ }^{79}$ Slaight Communications Inc v Davidson (1989) 59 DLR (4th) 416 at [95] (as per Lamer J).

${ }^{80}$ West Virginia State Board of Education v. Barnette, 319 U.S. 624 (1943).

${ }^{81}$ At 625. See also: Laurie Allen Gallancy "Teachers and the Pledge of Allegiance" (1990) 57 U Chic L Rev 929 at 931.

${ }^{82}$ Gallancy, above n 81, at 932.

${ }^{83}$ Riley $v$ National Federation of the Blind (1988) 487 US 781 at 797-798. See also: Gallancy, above $\mathrm{n}$ 81 , at 932.

${ }^{84}$ Riley $v$ National Federation of the Blind, above $\mathrm{n} 83$, at 784.

${ }^{85}$ Geiringer and Price, above n 76, at 320. See also: Brooker v Police [2007] 3 NZLR 91 at [114] per McGrath J; Hosking v Runting [2005] 1 NZLR 1 at [233] per Tipping J; Morse v R [2010] 2 NZLR 625
} 

a) Self-fulfillment
b) The importance of discovering truth
c) Participation in democracy

\section{A Self-fulfillment}

"A right to express beliefs and political attitudes instantiates or reflects what it is to be human." 86 Under the self-fulfilment rationale, free speech is an intrinsic good, which can lead to more insightful and mature individuals, thus benefiting society as a whole. ${ }^{87}$ If certain ideas or opinions are restricted, individuals who wish to pursue or explore those ideas may end up frustrated and consider the restrictions affronts to their inherent human dignity. ${ }^{88}$ People should be treated as capable of rational and autonomous thought by allowing them all the information possible to make wellinformed, rational, autonomous decisions. ${ }^{89}$ This underlying principle applies to all kinds of expression, including hate speech, but it does not easily extend to non-natural persons, such as corporations and the media. ${ }^{90}$

A right of reply directly contravenes the self-fulfilment rationale by disallowing an individual to freely choose what he might wish to express. Forcing a person to state something they don't believe or don't wish to say may frustrate them and make them feel like they are not being given the opportunity to rationally and autonomously conduct themselves. This rationale applies to all forms of speech, and so almost any forced online communication could impact a person's dignity and right to selfdetermination and fulfilment.

at [86]; Vincent Blasi "Free Speech and Good Character: From Milton to Brandeis to the Present" in Lee C. Bollinger and Geoffrey R Stone (eds) Eternally Vigilant: Free Speech in the Modern Era (University of Chicago Press, Chicago, 2002) at 61.

${ }^{86}$ Eric Barendt Freedom of Speech ( $2^{\text {nd }}$ ed, Oxford University Press, New York, 2005) at 13.

${ }^{87}$ At 13.

${ }^{88}$ Kent Greenawalt "Free Speech Justifications" (1989) 89 Colum L Rev 119 at 145.

${ }^{89}$ At 150.

${ }^{90}$ Barendt, above n 86, at 15-16. 


\section{B The Importance of Discovering Truth}

The discovery of truth is generally associated with John Stuart Mill. ${ }^{91}$ Mill's position was that truth is a fundamentally good concept, and particular truths are capable of being discovered and legitimized. ${ }^{92}$ Mill's theory rests on the idea that truth will be discovered through open debate. Neither true nor false speech should be prohibited, as both are required to challenge and defend ideas. ${ }^{93}$ Moreover, if restrictions start being placed on speech, even if it is seen to be false, there is a chance that true speech will also be suppressed. ${ }^{94}$ This is also known as the "marketplace of ideas" theory. ${ }^{95}$ It is unclear whether Mill envisaged the same protection for all types of speech; his theory leaves open the question of whether or not a distinction should be drawn between claims of fact and opinion. ${ }^{96}$ Propositions that cannot be objectively tested, such as hate speech, may fall outside of Mill's protection. ${ }^{97}$ This rationale is also not very helpful when it comes to situations where the speech complained of is not false but there may still be justifications for suppressing it, as in cases of breach of confidence or privacy. ${ }^{98}$ Although, according to this rationale, one could say that most speech on the Internet contributes to the marketplace of ideas, as even false speech should not be prohibited in order to challenge and reveal the truth.

A right of reply may make people less inclined to publish information on the Internet; people may feel like there is little point in expressing their own opinions if they are just going to be forced to publish a reply. This is regarded as the "chilling effect" on free speech. ${ }^{99}$ The chilling effect results in less available information, which might result in a less robust marketplace of ideas. In the case of Miami Herald Publishing Co. v Tornillo (Miami Herald case), ${ }^{100}$ the US Supreme Court ruled a right of reply provision to be unconstitutional in relation to the First Amendment guarantee of a free

\footnotetext{
${ }^{91}$ Barendt, above n 86 , at 7.

${ }^{92}$ At 7-8.

${ }^{93}$ At 8. See also: Lange v Atkinson and Australian Consolidated Press New Zealand Ltd, above n 14, at 50-51.

${ }^{94}$ Greenawalt, above n 88 , at 130.

${ }_{95}$ Barendt, above n 86, at 11.

${ }^{96}$ At $9-10$.

${ }^{97}$ At 10.

${ }^{98}$ Barendt, above n 86, at 10.

${ }^{99}$ Andras Koltay “The Right of Reply: A Comparative Approach" (2007) 4 Iustum Aequum Salutare 203 at 205.

${ }^{100}$ Miami Herald Publishing Co. v. Tornillo, 418 U.S. 241 (1974).
} 
press due to a primary concern was that a right of reply would chill speech from the media; ${ }^{101}$ it might prevent the media from publishing certain stories, stifling the marketplace of ideas. The Court held that newspapers should be able to freely choose what they wish to publish and rejected the "access-argument" that the public should have access to non-monopolising media in order to have a fully functioning marketplace of ideas. ${ }^{102}$

The US First Amendment rights include rights of both the speaker and the listener, but the speaker's interests are paramount. ${ }^{103}$ Listeners have a right to genuine expression, as they are entitled to an uninhibited marketplace of ideas in order to seek truth. ${ }^{104}$ A right of reply may force a speaker to relay disingenuous statements, which could create bias in the marketplace, whilst the chilling effect of a right of reply might also prevent information from being contributed to the marketplace from the very beginning, thereby infringing listeners' interests in having access to an unbiased and thriving marketplace of ideas.

\section{Participation in Democracy}

The argument from democracy posits that, the more the public is informed, the better their government and subsequent political decisions will be. ${ }^{105}$ This principle rests on the assumption that democracy is the best form of governance and social organisation. ${ }^{106}$ Democracy is conceptualised as rule by the people; the government acts as a servant, and the people must be fully informed to make their own decisions regarding governance. ${ }^{107}$ Since the people are sovereign, it should not be up to the government to decide what is true, especially when it comes to political information. ${ }^{108}$

\footnotetext{
${ }^{101}$ Larry Alexander "Compelled Speech" (2006) 23 Const Comment 147 at 149-150.

102 Charles Danziger "The Right of Reply in the United States and Europe" (1986-1987) 19 NYU J Int'l L \& Pol 171 at 176-177.

${ }^{103}$ Dayna B Royal "Resolving the Compelled-Commercial-Speech Conundrum" (2011) 19 Va J Soc Pol'y \& L 205 at 208.

104 At 210.

105 Greenawalt, above n 88, at 146.

${ }^{106}$ Frederick Schauer Free Speech: a philosophical enquiry (Cambridge University Press, New York, 1982) at 35.

${ }^{107}$ At 38.

${ }^{108}$ Schauer, above n 106, at 39.
} 
It is too simplistic to suggest that only political speech contributes to the formation of political ideas and the participation in democracy. ${ }^{109}$ Democracy requires its participants to be fully engaged with political issues so they can form their own informed opinions and then vote according to them. ${ }^{110}$ It therefore requires citizens to be the type of people that engage with issues and are capable of forming such opinions. A citizen is more likely to become such a person if he feels he is a valued member of society, worthy of equal respect and human dignity. ${ }^{111}$ As discussed above, freedom to express opinions, especially unpopular ones, can be essential to one's sense of self-worth and human dignity, which is "a foundational part of the political and civic cultures of pluralistic democracy." ${ }^{112}$ Moreover, a citizen should have enough knowledge to put political issues into context. In these ways, the argument from democracy incorporates both the truth and self-fulfilment rationales of freedom of expression.

One could argue that free speech is at least more likely than suppression to mould individuals into agents that can and will participate in a democratic system by encouraging rationality through the free marketplace of ideas, extending the democratic participation rationale to some non-political expression. ${ }^{113}$ By not allowing individuals to freely choose what they wish to express, and potentially restricting information from the marketplace or preventing self-fulfilling speech through a chilling effect, the right of reply impinges both the rationales of selffulfilment and the search for truth. This can prevent individuals from becoming the autonomous and rational individuals required by a functional democratic society. In this way, a right of reply arguably infringes the rationale of democratic participation.

However, insofar as the argument from democracy engages with the marketplace rationale, this theory of free speech rests on the assumption of "equal competence and universal rationality" arguably not found amongst the general public. ${ }^{114}$ A more

\footnotetext{
${ }^{109}$ Juliet Moses "Hate Speech: Competing Rights to Freedom of Expression" (1996) 8 Auckland U L Rev 185 at 192.

${ }^{110}$ Lange v Atkinson and Australian Consolidated Press New Zealand Ltd, above n 14, at 46. See also: Hopkinson v Police [2004] 3 NZLR 704 (HC) at [20].

${ }^{111}$ Barendt, above n 86, at 20.

112 Randal Marlin Propaganda and the Ethics of Persuasion (Broadview Press Ltd, Ontario, 2002) at 231.

113 Blasi, above n 83, at 85-87.

${ }^{114}$ Blasi, above $\mathrm{n} 83$, at 39-41.
} 
persuasive argument for democracy as a basis for free speech is its ability to be used as a check on government powers. ${ }^{115}$ Moreover, by allowing citizens to speak freely, freedom of expression can preserve society and prevent revolution and social harm by allowing people to vent their frustrations instead. ${ }^{116}$ This would narrow the application of this free speech principle to public or political matters. ${ }^{117}$ The US Supreme Court in the Miami Herald case argued that a right of reply can directly impinge on the functioning of democracy. ${ }^{118}$ Listeners' interests are central to compelled speech cases in the US, particularly where speakers are forced to disingenuously persuade listeners towards the government's position, as this undermines the true consent of those being governed making it unacceptable in a democracy. ${ }^{119}$ Listeners have the right to hear free expression unrestrained by government compulsion. ${ }^{120}$

\section{Conclusion}

A right of reply not only infringes a speaker's right to self-fulfillment, but also negatively impacts listeners' interests in the search for truth and the functioning of democracy, ${ }^{121}$ constituting an infringement on freedom of expression.

\section{Balancing Freedom of Expression and Protection of Reputation: What is the Best Form of a Right of Reply?}

Since a right of reply constitutes a prima facie breach of freedom of expression, this section determines whether this breach is demonstrably justifiable in a free and democratic society according to section 5 of the NZBORA. This paper considers the test set out by Tipping $\mathrm{J}$ in the New Zealand Supreme Court decision of $R v$ Hansen,

\footnotetext{
115 at $43-44$.

${ }^{116}$ Marlin, above n 112, at 228.

117 Schauer, above n 106, at 44.

${ }_{118}$ Miami Herald Publishing Co. v. Tornillo, above n 100. See also Danziger, above n 102, at 176.

119 Royal, above n 103, at 208.

${ }^{120}$ At 210.

${ }^{121}$ At $211-212$.
} 
as his methodology has since been endorsed by the Court of Appeal in Ministry of Health $v$ Atkinson: ${ }^{122}$

(a) does the limiting measure serve a purpose sufficiently important to justify curtailment of the right or freedom?

(b)

(i) is the limiting measure rationally connected with its purpose?

(ii) does the limiting measure impair the right or freedom no more than is reasonably necessary for sufficient achievement of its purpose?

(iii) is the limit in due proportion to the importance of the objective?

The scope and availability of a right of reply will influence how justified its breach of freedom of expression is. In light of this, this section also considers when and how a right of reply should be used under this new regime in order to constitute a limit on freedom of expression that is no more than reasonably necessary to protect reputation.

\section{A Does the Limiting Measure Serve a Purpose Sufficiently Important to Justify Curtailment of the Right or Freedom?}

The first question to ask when dealing with a limitation on a right is whether the objective sought by that limitation is sufficiently important. ${ }^{123}$ Both Tipping J regards this limb as a threshold test, with a lot of deference being given to Parliament on the issue. ${ }^{124}$ This means that, where a limiting measure is a matter of policy, according to Tipping J, it will be easily satisfied and the courts should not need to engage in much detailed analysis. However, for the purposes of this paper, this section provides a more detailed examination as to whether a right of reply does indeed serve an important purpose.

\footnotetext{
${ }^{122} R v$ Hansen [2007] NZSC 7 [2007] 3 NZLR 1 at [104] as per Tipping J and Ministry of Health $v$ Atkinson [2012] 3 NZLR 456 (CA) at [143].

${ }^{123} R v$ Hansen, above $\mathrm{n} 122$, at [104].

${ }^{124}$ At [121] as per Tipping J. See also [203] and [207] as per McGrath J.
} 


\section{The purpose of a right of reply}

A right of reply is typically a remedy for defamation or infringement of personality rights. ${ }^{125}$ Germany and France's right of reply provisions are designed to protect personality rights endorsed in their Civil Codes and the European Convention on Human Rights. ${ }^{126}$ Grounds for a right of personality can be found in a number of French and German statutes. ${ }^{127}$ In English, Article 2(1) of Germany's Basic Law states that: ${ }^{128}$

Every person shall have the right to free development of his personality insofar as he does not violate the rights of others or offend against the constitutional order or the moral law.

Whilst Article 1(1) says, "Human dignity shall be inviolable. To respect and protect it shall be the duty of all state authority." ${ }^{129}$ Section 823 of the German Civil Code states that: ${ }^{130}$

A person who, intentionally or negligently, unlawfully injures the life, body, health, freedom, property or another right of another person is liable to make compensation to the other party for the damage arising from this.

Personality rights are considered "another right" under section $823 .{ }^{131}$ Article 9 of the French Civil Code states that:

Everyone has the right to respect for his private life.

Without prejudice to compensation for injury suffered, the court may prescribe any measures, such as sequestration, seizure and others, appropriate to prevent or put an end

\footnotetext{
${ }^{125}$ Youm above n 13, at 1038. See also: McNamara, above n 14, at 92.

${ }^{126}$ Georges Rouhette and Anne Rouhette-Berton "English Translation of the French Civil Code" (4 April 2006) Legifrance <http://www.legifrance.gouv.fr/Traductions/en-English/Legifrancetranslations $>$, art 9. See also: Gounalakis, above n 13, at 66 and 69.

${ }^{127}$ Gounalakis, above n 13, at 66 and 69.

${ }^{128}$ Inter Nationes "English Translation of Basic Law for the Federal Republic of Germany (Grundgesetz, GG)" IUSCOMP < http://www.iuscomp.org/gla/statutes/GG.htm\#2> art 2(1).

${ }^{129}$ Inter Nationes, above n 128, Art 1(1).

${ }^{130}$ Civil Code in the version promulgated on 2 January 2002 (Federal Law Gazette [Bundesgesetzblatt] I page 42, 2909; 2003 I page 738), last amended by Article 1 of the statute of 27 July 2011 (Federal Law Gazette I page $1600<\mathrm{http}: / /$ www.gesetze-im-internet.de/englisch_bgb/englisch_bgb.html>, s 823

${ }^{131}$ Raymond Young "Marlene Dietrich Case BGH 1 ZR 49/97 (1 December 1999)" (1 December 2005) The University of Texas: School of Law

$<\mathrm{http}$ //www.utexas.edu/law/academics/centers/transnational/work_new/german/case.php?id=726>
} 
to an invasion of personal privacy; in case of emergency those measures may be provided for by interim order.

Finally, Article 8 of the European Convention on Human Rights states that: ${ }^{132}$

1. Everyone has the right to respect for his private and family life, his home and his correspondence.

2. There shall be no interference by a public authority with the exercise of this right except such as is in accordance with the law and is necessary in a democratic society in the interests of national security, public safety or the economic well-being of the country, for the prevention of disorder or crime, for the protection of health or morals, or for the protection of the rights and freedoms of others.

New Zealand does not have a general right to personality or respect for private life in the NZBORA. ${ }^{133}$ New Zealand has affirmed a right to privacy in the development of the privacy tort, ${ }^{134}$ though it is still in its infancy and not the equivalent of a general right to personality akin to Article $8 .{ }^{135}$ However, the New Zealand legal system has long enforced defamation laws. ${ }^{136}$ The raison d'être of defamation law is to protect reputation. ${ }^{137}$ Thus, New Zealand has arguably affirmed a right to protection of reputation through the implementation of defamation laws, ${ }^{138}$ for which right of reply has been used as a remedy in other jurisdictions. ${ }^{139}$ Therefore it makes more sense for the New Zealand courts to implement a right of reply on the basis of reputational rights as opposed to a general personality right. This section will examine the rationales behind an individual's right to have their reputation protected, and how a right of reply advances those rationales.

\footnotetext{
${ }^{132}$ European Convention for the Protection of Human Rights and Fundamental Freedoms, as amended by Protocols Nos 11 and 145 ETS (4 November 1950) art 8. (European Convention on Human Rights) ${ }_{133}$ Andrew Butler and Petra Butler "Protecting Rights" in Caroline Morris, Jonathan Boston and Petra Butler (eds) Reconstituting the Constitution (Springer, Heidelberg, 2011) at 176-177.

${ }^{134}$ Hosking $v$ Runting, above $\mathrm{n} 83$, at [148] as per Gault $\mathrm{P}$ and Blanchard J, and [259] as per Tipping J.

${ }^{135}$ Huw Beverley-Smith, Ansgar Ohly and Agnes Lucas-Schloetter, above n 15, at 207.

${ }^{136}$ Ursula Cheer and John Burrows "Defamation" in Stephen Todd et all (eds) The Law of Torts in New Zealand $\left(6^{\text {th }}\right.$ ed, Brookers, Wellington, 2013) at 811-812. See also: Defamation Act 1954 and Defamation Act 1992.

${ }^{137} \mathrm{McNamara}$, above n 14, at 92. See also: Lange v Atkinson and Australian Consolidated Press NZ Ltd, above n 14, at 30 and Television New Zealand Ltd v Quinn, above n 14, at 37-38.

${ }^{138}$ See discussion in: Lange v Atkinson and Australian Consolidated Press NZ Ltd, above n 14, at 30 and Television New Zealand Ltd v Quinn, above n 14, at 37-38.

${ }^{139}$ Donnelly, above n 12 , at $884-885$.
} 


\section{Rights to reputation}

The rationales for protection of reputation are not as well-defined as the ones for freedom of speech. ${ }^{140}$ Nonetheless, historically, the common law has been very protective of it. ${ }^{141}$ Indeed, since the turn of the nineteenth century, protection of reputation has been the raison d'etre of defamation law. ${ }^{142}$ Reputation has since been seen as something inherently good, deserving of protection. ${ }^{143}$ Moreover, it is recognised in Article 17 of the International Covenant on Civil and Political Rights, ${ }^{144}$ as well as Article 8 of the European Convention on Human Rights. ${ }^{145}$ Reputations are basically social judgements of individuals based on facts considered relevant by their particular community. ${ }^{146}$ They are what distinguish us; without a reputation, one could almost be considered a nonentity. ${ }^{147}$

Reputation forms the basis for decisions about who to employ, or do business with, or vote for, ${ }^{148}$ as it can be considered a means by which to judge a person's trustworthiness. Trust can be seen as linked to the concept of social capital. ${ }^{149}$ "Social capital" features networks, norms and values which aid cooperation and organization between two or more people for mutual benefit. ${ }^{150}$ When a group of people become embedded in these norms and values, they have a better idea as to whether or not they should trust each other and normally trust will ensue. ${ }^{151}$ Trust stabilises and increases cohesion and facilitates cooperation and success within society, whilst benefiting individuals by encouraging boldness and creativity and enriching their personal relationships. ${ }^{152}$ A person's reputation can be evidence upon which people will pass

\footnotetext{
${ }^{140}$ Robert C Post "The Social Foundations of Defamation Law: Reputation and the Constitution" (1986) 74 Cal Rev 691 at 692.

${ }^{141}$ Reynolds $v$ Times Newspapers Ltd [2001] 2 AC 127 at 192.

${ }^{142}$ McNamara, above n 14, at 92.

143 At 94.

144 International Covenant on Civil and Political Rights, 999 UNTS 171 (signed 16 December 1966, entered into force 23 March 1976) art 17.

${ }^{145}$ European Convention on Human Rights, above n 134, art 8.

${ }^{146}$ McNamara, above n 14, at 31.

${ }^{147}$ A O Ferrers "The law is right to value reputation more than life or limb" (1990) 4 NZLJ 152 at 152

${ }^{148}$ Reynolds $v$ Times Newspapers Ltd, above n 141, at 201.

${ }^{149}$ Francis Fukuyama "Differing Disciplinary Perspectives on the Origins of Trust" (2001) 81 B U L Rev 479 at 479.

${ }^{150}$ At 480 .

151 At 480.

${ }^{152}$ Helen Nissenbaum “Securing Trust Online: Wisdom or Oxymoron?” (2001) 81 B U L Rev 635 at 641-642.
} 
judgment as to whether they are trustworthy or not, ${ }^{153}$ and therefore whether or not they should be readily included within a societal framework. Protection of reputation can therefore be seen as a public, as well as individual, good. ${ }^{154}$

Robert Post posits three possible underlying rationales for the protection of reputation: ${ }^{155}$
(a) property;
(b) honour; or
(c) dignity

How one conceptualises the rationales underpinning protection of reputation can affect the outcome of one's analysis comparing freedom of expression and a right to reputation. ${ }^{156}$ This paper agrees with Post that dignity is the most appropriate rationale for protection of reputation.

\section{(a) Property}

Reputation can be seen as the fruits of hard work and skill in integrity and honourable living, and to injure a person's reputation is to destroy those hard-earned results, making it something akin to a person's property. ${ }^{157}$ Thus, defamation law only protects measurable harms to reputation and not mere hurt feelings. ${ }^{158}$ However, this theory of reputation cannot explain why, in defamation law, a claimant must prove a communication was defamatory in order to succeed, even if the communication has caused a pecuniary or personal loss. ${ }^{159}$ Moreover, often claimants, especially if they are in the public eye, don't bring defamation suits solely for damages; rather, they sue to vindicate their reputation. ${ }^{160}$ Furthermore, a presumption of damages can often be seen as an unjustified windfall in a market society. ${ }^{161}$

\footnotetext{
153 At 644 .

${ }^{154}$ Reynolds $v$ Times Newspapers Ltd, above n 141, at 201.

155 Post, above n 140, at 693.

156 At 722.

157 At 694-695.

158 At 695.

159 At 697.

${ }^{160}$ Robert N Bellah "The Meaning of Reputation in American Society” (1986) 74 Cal L Rev 743 at 744.

${ }^{161}$ Post, above n 140, at 706.
} 
(b) Honour

The theory of honour as the basis of reputation places the value of reputation above that of the market by making it a form of honour. ${ }^{162}$ Post argues that, instead of building honour themselves, people claim a right to it by virtue of their social status; one must live up to this honour by personifying those attributes. ${ }^{163}$ Thus, this theory presupposes inequality, and gives reputation a fixed value. ${ }^{164}$ The honour rationale is therefore best reserved for hierarchical societies. Honour cannot be obtained individually through hard work; instead it is attributed to certain social roles, though it can be lost through inappropriate behaviour. ${ }^{165}$ This suggests that people cannot rebuild their reputations through hard work, which is not always the case. Reputations are worth protecting, because damage to reputation also constitutes damage to the social status within which society has invested. ${ }^{166}$ This theory endeavours to explain the distinction between "defamatory" and "non-defamatory" remarks by conceptualising them as a question of whether the communication impacts honour or not. ${ }^{167}$ Moreover, damages can be seen as a means of vindicating the claimant's honour, even when there is no pecuniary loss. ${ }^{168}$ However, the idea that everyone is equal before the law, which is embedded in many Western democratic societies, suggests a rejection of the honour rationale. ${ }^{169}$

\section{(c) Dignity}

The last rationale advanced by Post is the dignity rationale, which posits that every person has essential human dignity and should be treated accordingly. ${ }^{170}$ This system is played out through rules of deference and demeanour; deference is conduct through which a person conveys appreciation to a person about that person, whilst demeanour is conduct by which an individual expresses his own personal qualities. ${ }^{171}$ Through

\footnotetext{
162 Post, above n 140, at 699.

163 At 700.

${ }^{164}$ At 700.

165 At 701 .

166 At 702.

167 At 706.

168 At 706.

169 At 726.

${ }^{170}$ At 707.

${ }^{171}$ At 709.
} 
this system, "an individual must rely on others to complete the picture of him of which he himself is allowed to paint only in certain parts." ${ }^{172}$ Our sense of self-worth is dependent on the respect it is given from other people; the dignity that defamation law protects is the respect that comes from full participation in society. ${ }^{173}$ The rules of deference and demeanour serve as social boundaries to preserve the stability of communal life. ${ }^{174}$ Defamation laws can be regarded as a means of preventing breaches of rules of deference and demeanour. ${ }^{175}$ They also serve to help define what a community is; "a community is a community because its members share an idea of what is 'decent"'. 176

A common test for defamation within the law of New Zealand is whether a statement has lowered the plaintiff in the eyes of a right-thinking member of society. ${ }^{177} \mathrm{By}$ determining what a right-thinking society believes, defamation law determines who is excluded and who is included within a certain conception of society. ${ }^{178}$ The law thus protects an individual's interest in being included within the boundaries of social respect, while enforcing society's interest in maintaining and defining its own social constitution. ${ }^{179}$ Recognition is what makes society functional, and reputation is an extension of that recognition. ${ }^{180}$ According to this theory, dignity is intrinsic and cannot be repaired through monetary compensation. ${ }^{181}$ Instead, a successful defamation claim provides the plaintiff with affirmation of membership in the community, designating them as worthy of respect. ${ }^{182}$

\section{Conclusion on the rationales for protecting reputation}

The honour model is limited to societies where social roles are well-established and used as a basis for determining social conduct; it is therefore no longer an adequate

\footnotetext{
172 Post, above n 140, at 709.

173 At 710-711.

174 At 711 .

175 At 710.

176 McNamara, above n 14, at 34.

177 Sim v Stretch [1936] 2 All ER 1237 (HL) at 1240 per Lord Atkin. Cited in Mount Cook Group Ltd v Johnstone Motors Ltd [1990] 2 NZLR 488 (HC) at 496-497. See also: The Christchurch Press Company Ltd v McGaveston Hilton Roger (13 December 1985) CA191/84 per McMullin J.

178 McNamara, above n 14, at 34.

${ }^{179}$ Post, above n 140, at 711-712.

${ }^{180}$ Bellah, above n 160, at 743.

${ }^{181}$ Post, above n 140, at 712.

182 At 712-713.
} 
model for society today. ${ }^{183}$ Instead, the conception of reputation as dignity better fits our modern, egalitarian and liberal society. A focus on individualism within society could be what leads to the impression that reputation is individualistic and more like property. ${ }^{184}$ A focus on individual success makes us forget how much we rely on others to succeed. ${ }^{185}$ This indicates a less individualistic conception of reputation and suggests that it is more of a public good, which coincides with the dignity rationale. ${ }^{186}$ This paper therefore considers that the dignity rationale is the most persuasive argument for protecting reputation. Consequently, the objective of a right of reply can be conceptualised as protecting individuals from statements that lower them in the eyes of right-thinking members of society, preventing them from being accurately and fairly judged and included within society as people deserving of equal respect and human dignity. This is an important objective, and should easily satisfy this threshold limb of the test set out in $R v$ Hansen.

\section{B Proportionality}

The following three stages of the Hansen analysis are concerned with proportionality. In determining whether a right of reply is a proportional limit on freedom of expression, it is important to establish when exactly a right of reply should be used and what form it should take. In order to do so, this paper draws on other established rights of reply in both New Zealand law and in other jurisdictions. The following sections will consider the rights of reply available in France, Germany and South Korea, well as aspects of the Broadcasting Standards Authority's (BSA) power to order the publication of statements and apologies because, like the right of reply proposed by the Commission, they are statutorily based.

Where a complaint is justified, the BSA has the power to make: ${ }^{187}$

an order directing the broadcaster to publish, in such manner as shall be specified in the order, and within such period as shall be so specified, a statement that relates to the complaint and that is approved by the Authority for the purpose

\footnotetext{
183 Post, above n 140, at 701-702.

${ }^{184}$ Bellah, above n 160, at 744.

185 At 743-744.

186 At 744.

${ }^{187}$ Broadcasting Act 1989, s 13(1).
} 
This statement could be a general statement about the BSA's findings on a particular case, or an apology, ${ }^{188}$ and the BSA is entitled to review the statement to make sure it meets their approval before it is published. ${ }^{189}$

The French Press Act of 1881, which is still in force, sets out a right of reply in two ways: droit de rectification (right of rectification) for government officials (Article 12) and droit de reponse (right of reply) for ordinary individuals. ${ }^{190}$ This paper will focus on the droit de reponse because it would appear that the right of reply under the new regime might be available to ordinary citizens. A French Draft Decree regarding the right of reply on the Internet was proposed in $2007 .{ }^{191}$ It stipulates that the right of reply should be granted if a challenged Internet site refuses an opportunity for direct reply through forums or chat rooms. ${ }^{192}$ The German right of reply, which is "central to the rules of the state press laws," was "transplanted from the French Press Law of 1822 into the Baden Press Law of 1831 and then into the Imperial Press Law of 1874 as a demand for "correction." It is now incorporated into German law as a statutory concept through the Länder (federal states) press laws. ${ }^{193}$ Given the lack of availability of English translations of German legislation, this paper focuses on the right of reply provisions in the Press Law for the Free and Hanseatic City of Hamburg. ${ }^{194}$ Finally, South Korea first recognized the right of reply in 1980 under the Basic Press Act. ${ }^{195}$ In 2005, the Korean National Assembly enacted the Act on Press Arbitration and Remedies, etc., for Damage Caused by Press Reports ("Press Arbitration Act") as a comprehensive legal framework for news media-related complaints, which includes a provision detailing aspects of a right of reply. ${ }^{196}$

\footnotetext{
${ }^{188}$ Radio NZ v Ellis CIV 2004-485-2035 (HC) at [40]. See also: Steven Price Media Minefield (New Zealand Journalists Training Organisation, Wellington, 2007) at 5.

189 Anderson and Others and Cruise FM Waikato - 2012-133, 25 July 2013 at [39].

190 Youm, above $\mathrm{n} 13$, at 1034-1035.

${ }^{191}$ EDRI-gram, above n 65. See also: Youm, above n 13, at 1037.

192 EDRI-gram, above n 65. See also: Youm, above n 13, at 1037.

${ }^{193}$ Maximilian Ruhenstroth-Bauer "The right of reply in Germany" (13 February 2012) Free Speech Debate $<\mathrm{http}: / /$ freespeechdebate.com/en/case/the-right-of-reply-in-germany/> See also: Youm, above n 13 , at 1039 .

${ }^{194}$ Inter Nationes "English translation of Press Law for the Free and Hanseatic City of Hamburg (Hamburgisches Pressegesetz, HmbPG)" IUSCOMP

$<\mathrm{http}$ //www.iuscomp.org/gla/statutes/HmbPG.htm\#11>, art 11.

195 Youm, above n 13, at 1051.

196 Youm, above n 13, at 1052. See also: Supreme Court of Korea "Supreme Court Decision [Press Report Correction] Da86782 (November 15 2011)" Supreme Court of Korea $<$ http://library.scourt.go.kr/jsp/html/decision/9-64\%202012.11.15.2011Da86782.htm>
} 
The first question in the proportionality analysis asks whether a limit on a right is rationally connected with the objective it is trying to advance. ${ }^{197}$ Therefore, this section addresses whether a right of reply actually protects reputation. This paper agrees with Tipping J's assertion that this limb is also a threshold test, with a lot of deference given to Parliament; ${ }^{198}$ there should simply be a connection between the ends and means, but if there is no connection at all, then the limitation on freedom of expression cannot be justified. Tipping regards this limb as easily satisfied, because whether or not a limit is justified is essentially whether it is a justified end achieved by proportionate means; ${ }^{199}$ a question which is dealt with under the last two limbs of the Hansen test. With regards to the new regime, whether a right of reply actually protects reputation will depend on the circumstances in which it is used. A right of reply will not be the appropriate remedy for all harmful digital communications under the new regime because it should be limited to situations where a communication is harmful because it damages a person's reputation, and a right of reply will help repair it.

\section{How does a right of reply protect reputation?}

A right of reply can protect reputation by allowing a person to air their side of the story, encouraging people to fairly and accurately judge and include them within society as a person of equal respect and dignity. In this way, the right of reply advances the dignity rationale. A right of reply similarly advances the other rationales for the protection of reputation. A reply promotes the honour rationale by serving as vindication of one's honour and reputation. It can also extend to the property rationale, albeit in a less direct way, because it could stymie pecuniary loss but would not directly compensate for loss already suffered.

A right of reply will not serve to protect reputation in all of the circumstances set out by the Commission under this new regime. Indeed, a reply would have almost nothing

\footnotetext{
${ }^{197} R v$ Hansen, above $\mathrm{n}$ 123, at [64] and [104].

${ }_{198}$ At [121].

${ }^{199}$ At [123].
} 
to do with reputation when invoked against grossly offensive or threatening statements. This paper submits that a right of reply should only be used where a person's reputation is at stake, and a right of reply would adequately serve to protect that person's reputation. Under the new regime, a right of reply could thus be used to remedy the disclosure of sensitive personal facts, false allegations, or breach of confidence, where they prevent an individual from being accurately and fairly judged and included within society as people deserving of equal respect and human dignity.

2 Why a right of reply should extend beyond remedying false allegations that harm reputation

If the objective of a right of reply is to protect reputation, its application should extend to all situations where a statement harms reputation. In his book, The Future of Reputation, Daniel Solove explains why it may be relevant to restrict the revelation of sensitive facts about a person in order to protect their reputation. ${ }^{200}$ The dissemination of true facts can sometimes have a disproportionately detrimental effect on reputation. Sometimes it is important for us to conceal information about ourselves that other people might use to our disadvantage. ${ }^{201}$ This reasoning justifies the censoring of falsehoods that damage our reputations. ${ }^{202}$ The question is, how much more control should we have over our reputations? ${ }^{203}$ Should we be entitled to restrict the amount of true information about ourselves available in the public sphere ${ }^{204}$ Too much control can be restrictive on free speech, but too little control can lead to detrimental effects on reputation that can also affect people's liberty. ${ }^{205}$ A right of reply can strike a balance between these two concerns.

Gossip is fundamental to the establishment of reputations; reputations only exist within the conversations we have about one another. ${ }^{206}$ Through gossip, we expose people's moral and normative infringements, thus making it an essential tool for

\footnotetext{
${ }^{200}$ Daniel J Solove The Future of Reputation: gossip, rumour and privacy on the internet (Yale University Press, London, 2007) at 35 and 63-70.

201 At 35.

202 At 35 .

203 At 35 .

204 At 35.

205 At 35 .

${ }^{206}$ At 63.
} 
maintaining societal norms. ${ }^{207}$ The problem is that gossip is usually a mixture of halftruths and gossipers rarely seek out the full story. ${ }^{208}$ Often true information can be disseminated out of context, which could cause someone to form a distorted view about a person. ${ }^{209}$

Our knowledge of other people is often 'empty canvas'. There's a lot we don't know about our coworkers, our friends, and even our family members. When we discover new information about people, we can fill in the canvas, but we still often only have partial understanding. ${ }^{210}$

Moreover, we conduct ourselves differently depending on our environment. The persona we adopt at work may differ enormously from the person we are in the comforts of our own home. ${ }^{211}$ Solove suggests there is no "true" self, we are all configurations of several dimensions or facets; which dimension you reveal at a given time is made by a value judgement. ${ }^{212}$ Thus, new information about a person, revealed out of context, will not lead to a discovery of a "true" self and can instead be rather jarring and distorting, ${ }^{213}$ and people have a tendency to make irrational judgements based on stigmatised characteristics, especially when taken out of context. ${ }^{214}$ Society expects a person's "public self" to be less revealing, and unintended revelations of private information take away a person's right to self-determine when and if to reveal certain aspects about themselves, and may result in them being judged harshly for unwittingly revealing too much. ${ }^{215}$ A right of reply can help to put sensitve facts into context to make them less jarring and distorting. Where any information, whether true or false, has been disseminated in a way that prevents society from fairly or accurately judging a person as worthy of equal respect and dignity and inclusion within society, then a right of reply might be a justifiable remedy in order to restore a claimant's reputation.

\footnotetext{
207 Solove, above n 200, at 63 .

208 At 64 .

209 At 66.

${ }^{210}$ At 67.

${ }^{211}$ At 68.

212 At 69.

213 At 69.

214 At 70 .

215 At 69.
} 


\section{Conclusion on rational connection}

If, like our defamation law, a right of reply is grounded in the idea that protection of one's reputation is important, in order for it to be considered rationally connected to its objective, a right of reply should only be used against statements that have damaged reputation. In order to constitute damage to reputation, a statement must prevent a person from being accurately and fairly judged and included within society as someone deserving of equal respect and human dignity. This means that any statement that negatively affects a person's reputation could justify a right of reply, but the remedy could not simply be used against any untruth. For example, where sensitive personal facts have been given out of context, leading people to form unfair or distorted judgments about an individual, then a right of reply might be appropriately used to give the information context.

Under the newly proposed regime, a right of reply could potentially be used in cases where sensitive personal facts have been disclosed (principle one), or confidence has been breached (principle eight), or where false allegations have been made (principle seven), which has led to prejudiced or unfair judgement of the claimant. In summary, because a limit on freedom of expression must be rationally connected to its objective, a right of reply should only be limited to circumstances where it advances the protection of reputation, because otherwise it is not connected to its objective at all.

ii) Does the limiting measure impair the right or freedom no more than is reasonably necessary for sufficient achievement of its purpose?

The second stage of the proportionality analysis considers whether there are alternative, but less intrusive means of achieving Parliament's objective. ${ }^{216}$ The question to consider here is whether any other remedies under the new regime protect reputation whilst imposing less of an infringement on a defendant's right to free speech. Since the Commission and the Social Policy Committee have left a right of reply undefined, this section first considers when a right of reply might be used, and

${ }^{216} R v$ Hansen, above $\mathrm{n} 122$, at [126] and [217]. 
what form it should take, in order for it to constitute a minimal impairment on free speech whilst suitably meeting its objective of protecting reputation. It then examines other remedies available under the new regime, and any other measures claimants could use to protect themselves, and considers whether these other means infringe freedom of expression less than a proposed right of reply.

\section{When a right of reply should be used}

\section{(a) Distinctions between fact and opinion}

There is a question as to whether a right of reply should apply to statements of both fact and opinion, or just statements of fact. Under French law relating to newspaper publications, any statement, whether of fact or opinion, that relates to a claimant's personality, can be subject to a right of reply. ${ }^{217}$ On the other hand, German and South Korean rights of reply will only apply in relation to inaccurate facts. ${ }^{218}$ This section explains why it is desirable to distinguish between fact and opinion under this new regime, even though both types of statement can harm reputation, and explains how a Court should go about making that distinction under this new regime.

(i) Why it is important to distinguish between fact and opinion

New Zealand's defamation law currently distinguishes between fact and opinion through use of a defence of honest opinion, often referred to as "fair comment" in other jurisdictions. ${ }^{219}$ Statements of honest opinion are exempt from defamation claims because they embody the rationales underpinning freedom of expression more than statements of fact. Airing one's opinion can be self-fulfilling in the sense that, if one's opinion was censored for being irrational or inadequately developed, it could affect an individual's self-worth by causing them to feel less worthy of equal respect and human dignity. All opinions contribute to the marketplace of ideas in the search for truth, and the theory posits that any disparity arising from irrational opinions will work itself out within the marketplace of ideas where truth always wins out in the

\footnotetext{
217 Gounalakis, above n 13, at 64 .

218 Youm, above n 13, at 1039 and 1055.

${ }^{219}$ Defamation Act 1992, s 9.
} 
end. ${ }^{220}$ The right to participate in the democratic process includes the right to develop well-informed political opinions, and one can determine if an opinion is welldeveloped and informed by having it challenged by opposing opinions. ${ }^{221}$

Opinions are often distinguished from fact by their lack of verifiability. ${ }^{222}$ The more verifiable a statement is, the more factual it is in nature. The defence of honest opinion originated due to the lack of verifiability of opinions; without the defence, any defamatory statement that could not be verified would result in a win for the claimant. ${ }^{223}$ The lack of protection could lead to a chilling effect on speech, as people would be reluctant to air their own opinions, even if they were based on reasonable grounds, ${ }^{224}$ resulting in a stagnant marketplace of ideas.

However, the distinction between fact and opinion fails to acknowledge the influence of the speaker. ${ }^{225}$ Even if the writer clearly identifies a statement they have made as opinion, if that person is of particular importance or social standing, a reader may still treat their opinion as fact, perhaps thinking that there are other undisclosed facts upon which the statement was based. ${ }^{226}$ Ungrounded or biased opinions can be just as damaging as misstated facts. ${ }^{227}$ Even so, statements of honest opinion engage the rationales of free speech theory in a way that misstatements of fact do not, so it is nonetheless desirable to distinguish between the two in order to satisfactorily balance the defendant's freedom of expression against a claimant's right to have their reputation protected. This is a question to be considered in more depth under the last limb of the Hansen balancing test.

\footnotetext{
${ }^{220}$ Herbert W Titus "Statement of Fact Versus Statement of Opinion - A Spurious Dispute in Fair Comment” (1961-1962) 15 V \& L Rev 1203 at 1207.

${ }^{221}$ At 1208.

${ }^{222}$ Fredrick Schauer "Language, Truth and the First Amendment: An Essay in Memory of Henry Canter" (1978) 64 Va Law Rev 263 at 277.

223 Titus, above n 220, at 1209.

224 At 1209.

${ }^{225}$ At $1212-1213$.

226 Jerry J Phillips “Opinion and Defamation: The Camel in the Tent” (1989-1990) 57 Ten L Rev 647 at 651 .

${ }^{227}$ At 657.
} 
(ii) How to distinguish between fact and opinion

In determining whether a statement is fact or opinion, the New Zealand courts have taken a context-based approach, ${ }^{228}$ which is advocated by Rodney Ott. ${ }^{229}$ Context can colour the meaning of words and can influence the degree of ambiguity surrounding them. ${ }^{230}$ For example, the words, "Dr Smith is a murderer" could be considered a factual statement that is defamatory. However, when you place them on a placard outside an abortion clinic where Dr Smith works, they start to seem more like opinion. ${ }^{231}$ In determining whether a statement is fact, a factor to consider is its precision or verifiability, ${ }^{232}$ and context can shape how precise a statement is. ${ }^{233}$ The more certainty one can have in the verifiability of a statement, the more factual it is. For example, the fact that "X owns a Ford Focus" can be checked out to a high level of certainty. ${ }^{234}$ However, not everything considered "fact" fits into this narrow conception. ${ }^{235}$ For example, one might consider the statement that "cigarettes are bad for your health" to be a factual statement, yet it cannot be held up to the same standard of verifiability as the Ford Focus statement. ${ }^{236}$ Thus, verifiability can be considered as a spectrum; the more verifiable a statement, the more confident we can be that it is factual in nature. ${ }^{237}$ At the opposite end of the spectrum are purely normative judgments of the individual speaker, ${ }^{238}$ as value judgments are almost impossible to verify. ${ }^{239}$

Herbert Titus gives further guidance by suggesting that the test for whether a statement is opinion or fact should rest on the "probability that the reader or the hearer will be misled in the formation of what he thinks of the person talked about". ${ }^{240}$ The probability of this occurring is higher when the facts upon which the writer has based

\footnotetext{
${ }^{228}$ Mitchell $v$ Sprott [2002] 1 NZLR 766 at [17].

${ }^{229}$ Rodney W Ott "Fact and Opinion in Defamation: Recognizing the Formative Power of Context" (1990) 58 Fordham Law Rev 761 at 784.

${ }^{230}$ At 786.

${ }^{231}$ At 786.

232 Schauer, above n 222, at 277.

${ }^{233}$ Ott, above n 229, at 787.

${ }^{234}$ Schauer, above n 222, at 277.

235 At 278.

${ }^{236}$ At 278.

237 At 279

238 At 279 .

239 Titus, above n 220, at 1210 .

${ }^{240}$ At $1235-1236$.
} 
his opinion have been withheld from the reader. ${ }^{241}$ Therefore, in order to have a statement classified as opinion, it "must inform its reader or hearer why the writer or the speaker thinks the way he does about the person talked about." ${ }^{242}$ Thus, for example, the statement that " $\mathrm{X}$ is immoral" may be regarded as fact because the reader assumes the writer has some facts to base this conclusion on. ${ }^{243}$ Whereas the statement that " $\mathrm{X}$ stole money from $\mathrm{Y}$ and is therefore immoral" is a clear mixture of fact and opinion, ${ }^{244}$ as readers are left free to decide for themselves whether stealing money is immoral or not. This reasoning is mirrored in Lord Phillips' judgment in the English Supreme Court decision of Joseph v Spiller, ${ }^{245}$ endorsing Lord Nicholls' reasoning in the Hong Kong Court of Appeal decision in Tse Wai Chun v Cheng. ${ }^{246}$ Lord Phillips is of the view that a statement will be regarded as opinion where it identifies, at least in general terms, why the writer made that comment, so the reader can understand what the statement is about, and the commentator can explain why they expressed the views that they did when challenged about it. ${ }^{247}$ Under Lord Phillips' view, there is no need to explicitly (or implicitly) point to the facts upon which the statement was based, ${ }^{248}$ but it would be desirable to indicate the nature of the facts upon which the statement is made. ${ }^{249}$ By divulging the nature of the facts upon which a conclusion is made, the writer will give readers more context, and help to clarify what was meant by the conclusion.

(iii) Conclusion

The Court should determine whether a statement is fact or opinion by considering the context within which it was made, how likely it is to mislead a reader, whether facts upon which a statement was made have been provided, and how verifiable the statement is. Whether or not a statement is fact or opinion will be a relevant consideration at the last stage of the balancing test, when considering the value of the

\footnotetext{
241 Titus, above n 220, at 1241.

242 At $1239-1240$.

${ }^{243}$ Phillips, above n 226, at 667.

${ }^{244}$ At 667.

${ }^{245}$ Joseph $v$ Spiller [2010] UKSC 53, [2011] 1 AC 852 at [3] and [105].

${ }^{246}$ Tse Wai Chun v Cheng [2001] EMLR 777 at [16]-[21].

247 Joseph $v$ Spiller, above n 245, at [104].

248 At [98].

249 At [103].
} 
speech used in the original harmful communication and whether a right of reply is a proportional response.

\section{(b) Exemptions}

In Germany and South Korea, fair and accurate reports of open governmental proceedings and commercial adverts are exempt from right of reply orders. ${ }^{250}$ This paper does not think that a right of reply should not be available for use against commercial adverts online. There has been an increase of false testimonials for products and services online. ${ }^{251}$ Companies have resorted to scouring Facebook for people's full names and photos and then using them to endorse their products without their knowledge. ${ }^{252}$ Although a takedown might be considered suitable in such cases, a reply would have the effect of not only getting the claimant's side of the story out in the open, but it would also expose the truth about that particular company's unethical exploits.

In New Zealand, fair and accurate reports of Parliamentary proceedings are exempt from defamation claims, ${ }^{253}$ unless they were motivated by ill will. ${ }^{254}$ Parliamentary privilege exists to enable Parliamentarians to effectively carry out their duties, ${ }^{255}$ whilst reports of proceedings are protected because it is considered "of paramount importance that the public should see the making and administration of the law at work." 256 The public interest in knowing about Parliamentary proceedings overrides any individual reputational interests. ${ }^{257}$ A right of reply may pose a chilling effect on reports of Parliamentary proceedings, as reporters may be less inclined to publish reports knowing that they may be forced to alter them. For consistency's sake, and

\footnotetext{
${ }^{250}$ Youm, above n 13, at 1039 and 1054.

${ }^{251}$ Mike Deri Smith "Fake Reviews Plague Consumer Websites" (26 January 2013) The Guardian < http://www.news.com.au/technology/public-asked-to-help-with-crackdown-on-fake-onlinetestimonials-and-the-removal-of-negative-reviews/story-e6frfro0-1226625385230>

${ }^{252}$ Drew “Stop Stealing my Sh*t!" Skinny Artist < http://skinnyartist.com/stop-stealing-my-images/> See also: Leah Parsons "A Company Stole a Picture of My Daughter Rehtaeh Parsons, Who Committed Suicide After Rape, and Used it on a Dating Ad on Facebook" (18 September 2013) xoJane: It Happened to Me < http://www.xojane.com/it-happened-to-me/rehtaeh-parsons-facebookdating-ad>

${ }^{253}$ Defamation Act 1992, s 16.

${ }^{254}$ Section 19.

${ }^{255}$ Enid Campbell Parliamentary Privilege (The Federation Press, Sydney, 2003) at 1.

${ }^{256}$ John Burrows and Ursula Cheer Media Law in New Zealand (LexisNexis NZ, Wellington, 2010) at 142.

${ }^{257}$ At $142-143$.
} 
due to the heavy public interest in hearing about the workings of Parliament, it may make sense to have an exemption for fair and accurate reports of Parliamentary proceedings. The fact that a report must be fair and accurate implies that any potential damage to reputations from such reports would be minimal in any case.

There is also a question as to whether there should be a distinction between public and private web pages, for example, whether rights of reply should be reserved for websites accessible to everyone, or whether they should extend to people's relatively private Facebook pages, where viewership can be concealed from the general public and restricted to a smaller number of people. The privacy settings on Facebook are variable, a user can set their own privacy preferences, but the default setting leaves a person's profile viewable by the public. ${ }^{258}$ However, even if one's Facebook profile is kept private and viewable only by Facebook "friends", readership can be diverse in terms of connections with the author. ${ }^{259}$ There is no determinative definition of what sort of relationship warrants a Facebook friendship, and a person's friends-base can range from strong to weak to non-existent ties. ${ }^{260}$ A person can be Facebook "friends" with you, even if you hardly know them at all. ${ }^{261}$ So while people may feel some sense of intimacy within their Facebook community, enough to be encouraged to share a wide range of personal information, the reality is that the information may be being shared with many people that person would not normally share such information with. Moreover, there is nothing to stop your "friends" from redistributing that information onto more public forums. It is therefore too hard to make a general distinction between public and private pages on the Internet and a right of reply should be available on sites such as Facebook where a claimant is unable to effectively remedy the damage done to their reputation through their own self-administered reply.

\footnotetext{
258 Justin Lafferty "STUDY: Confusing Facebook Privacy Settings Lead To More Public Information" (6 March 2013) AllFacebook: The Unofficial Facebook Blog < http://allfacebook.com/carnegiemellon-facebook-privacy-study_b112298>

${ }^{259}$ Ralph Gross and Alessandro Acquisti "Information Revelation and Privacy in Online Networks (The Facebook Case)" (paper presented at ACM Workshop on Privacy in the Electronic Society (WPES), Alexandria, Virginia, November 2005) at 2.

260 At 2-3.

261 At 3.
} 
(d) Time limits

Other jurisdictions place a time limit within which a complaint may be received about a publication. ${ }^{262}$ French law imposes a one-year time limit for complaints, ${ }^{263}$ while the South Korean courts will not impose replies to reports that are more than 6 months old. ${ }^{264}$ Under the French Draft Decree for rights of reply on the Internet, a request for the right to reply can be made in writing, acknowledging the manager of the respective site, within 3 months from the publication of the article that makes up the subject of the request, and the Webmaster must then publish the respective reply on the site within 3 days of receipt of the request. ${ }^{265}$ By limiting the applicability of a right of reply, a time limit for complaints would restrict infringements on freedom of expression.

However, due to the permanent nature of the Internet, there should not be time limits on a right of reply under the new regime. A claimant should not be refused a right of reply simply because they have only recently been made aware of damaging blog commentary two years after the last comment was made. Those comments could remain on the Web forever, and a quick Google search of a person's name might bring them out into the open again. There would constantly be a risk of someone finding the commentary, perhaps through a Google search, and reposting it somewhere else, thereby further damaging a person's reputation.

(e) Consideration of publisher's original intent

The Commission has proposed that information must simply cause significant emotional harm whilst relating to one of the ten enumerated principles in order to justify a remedy; the intent of the speaker doesn't have any bearing as to whether a defendant has breached one of the enumerated principles. The Commission has stated that it will be a relevant consideration when it comes to generally considering

\footnotetext{
262 Youm, above n 13, at 1035 and 1053.

263 At 1035.

264 At 1053 .

${ }^{265}$ EDRI-gram, above n 65.
} 
remedies. ${ }^{266}$ However, South Korean law stipulates that a newspaper's intent in the publication of the false facts will have no relevance in determining whether a right of reply is appropriate. ${ }^{267}$ This paper agrees with the South Korean approach in that a publisher's intent should not be deemed a highly relevant consideration as to whether a right of reply should be used. Regardless of the publisher's intent, a claimant's reputation has been damaged and deserves to have that damage restored.

\section{What form a right of reply should take}

(a) To whom should a right of reply be available?

This paper argues that, if the purpose of a right of reply is to protect reputation, then it should only be available to those whose reputation has been affected. The Commission has already limited remedies to those who have been significantly emotionally distressed by a harmful communication. ${ }^{268}$ Therefore, a right of reply should only be available under the new regime if a digital communication has caused significant emotional harm to an individual by damaging that individual's reputation. It should not extend to anyone simply named or affected by a statement, as in France. ${ }^{269}$ The South Korean right of reply is limited to "anyone with a legitimate interest" in the publication. ${ }^{270}$ The approach argued by this paper accords with the South Korean approach, in that a right of reply will only be available to those with a legitimate interest in protecting their reputation from an emotionally distressing statement.

\section{(b) Placement and availability}

A right of reply will often only protect reputation if is treated with similar respect to the original statement. Placement and context will be important; a small snippet buried under a maze of commentary will have less effect than an entire story on the subject. In France, if a defamatory article appears on the front page of a newspaper,

\footnotetext{
${ }^{266}$ Law Commission, above n 1, at [5.80]. See also: Cabinet Social Policy Committee, above n 4 at [58.1]-[58.9].

${ }^{267}$ Youm, above n 13, at 1054

${ }^{268}$ Law Commission, above n 1, at [5.66].

269 Youm, above n 13, at 1035

${ }^{270}$ At 1054.
} 
then the reply should also appear on the front page. The fact that a newspaper might have published a claimant's letter to the editor may not be sufficient. ${ }^{271}$ Under the French Draft Decree regarding rights of reply on the Internet, a reply must be made available "under similar conditions as those of the message under discussion and presented as a result of exercising the right to reply". ${ }^{272}$ Consequently, under this new regime, a reply should be in the same form as the original statement; it should appear in the same place and be the same type of article, ${ }^{273}$ and the fact that a website may allow individuals to comment will not in itself be enough to protect them from a right of reply order. A reply should also be made available for as long as the original statement is. ${ }^{274}$

\section{(c) Legality of the reply}

A reply should be legal. Consequently, the courts should be careful not to allow defamatory replies. Other jurisdictions also stipulate that the reply must be lawful. ${ }^{275}$ However, there are few restrictions on the French right of reply; it may also include statements of opinion, or value judgments, as opposed to just factual statements. ${ }^{276} \mathrm{~A}$ reply must simply not be calculated to cause harm to the honour of the editors, but the ultimate question is whether the reply is proportionate to the original article. ${ }^{277}$ This paper recommends that the New Zealand courts should accord with this principle and proposes that, like the BSA, the courts should be entitled to approve the wording of a reply. ${ }^{278}$ A reply should not be calculated to cause harm and its primary purpose should be to vindicate a claimant's reputation. South Korean law also states that a reply should not clearly contradict facts. ${ }^{279}$ The New Zealand courts should also be careful to not issue untrue replies, as such replies run the risk of being defamatory in themselves, thereby making them illegal, although it may be difficult to clearly determine whether a reply is true or not.

\footnotetext{
${ }^{271}$ Youm, above n 13, at 1040.

272 EDRI-gram, above n 65.

${ }^{273}$ Youm, above n 13, at 1035, 1039-1040 and 1057.

${ }^{274}$ EDRI-gram, above n 65.

275 Youm, above n 13, at 1035, 1039 and 1055

276 Gounalakis, above n 13, at 65 .

277 At 65.

278 Anderson and Others and Cruise FM Waikato, above n 189, at [39].

${ }^{279}$ Youm, above n 13, at 1054.
} 
(d) Cost to claimant

Whether a claimant should have to pay to have a reply published by a defendant should not be an issue in the context of the New Zealand regime. As discussed above, a reply should be identical to the original statement in both form and placement, and this regime only applies to harmful digital communications. All replies should therefore be published online, in which case there should be little or no cost involved at all. Nonetheless, the approaches in Germany and France both suggest that a right of reply should be free to the claimant, ${ }^{280}$ and the Social Policy Committee did not envisage the Court would be able to make an order for costs, ${ }^{281}$ so it would seem that if cost of publication is an issue, it is to be borne by the defendant.

\section{Summary of when and how a right of reply should be used}

A right of reply should be limited to those who have suffered significant emotional harm from a statement of fact or opinion that has harmed their reputation, by preventing them from being fairly judged as a person deserving of equal respect and dignity. A right of reply should be available in commercial contexts and should apply to websites that are considered "private", as well as those that are clearly in the public domain. The only exemption should be for fair and accurate reports of Parliamentary proceedings. Whether or not a defendant intended to harm the claimant's reputation should not be a relevant consideration, and there should be no time limits on when a claimant can ask for a reply. A reply should take the same form as an original statement, be found in the same place, and left available for as long as the original statement is available. The content of the reply should be legal and approved by the Court, and any costs are to be borne by the defendant.

\section{Other available remedies}

A right of reply helps to protect a claimant's reputation by allowing them to put forth their side of the story in response to statements that harm their reputation in order to provide context or a balanced perspective. This section considers whether other

\footnotetext{
${ }^{280}$ Youm, above n 13, at 1035 and 1040.

${ }^{281}$ Cabinet Social Policy Committee, above n 4, at [55.1]-[55.10].
} 
remedies under the proposed regime protect reputation just as well as a right of reply whilst posing less of an infringement on freedom of expression.

An order to cease conduct, or encouragement to engage in similar conduct, ${ }^{282}$ will typically not be beneficial if harmful statements are left published. Similarly, a declaration that a principle has been breached will not be useful, ${ }^{283}$ as a harmful statement will be left published. Moreover, an order for the release of a person's identity or name suppression will not be directly useful in response to a reputationally damaging statement published online. ${ }^{284}$ This paper considers that, like a right of reply, a takedown, apology or correction could be beneficial to a claimant's reputation by forcing the publisher to revoke the original statement. ${ }^{285}$ However, because a take down, apology or correction all require a defendant to fully remove an offensive statement, they completely restrict freedom of speech, whereas a right of reply leaves room to allow a defendant to leave his offensive statement in the open. The German courts consider a right of reply to be less imposing on free speech than a retraction or correction, because retractions and corrections have more of a direct effect on the original article, by either amending it or censoring it. ${ }^{286}$ If the Court is entitled to review the content of a reply to ensure it is not damaging in itself, it will not constitute more of a limitation on freedom of expression than a correction. Indeed, since a correction censors the defendant's speech, in most cases a reply may constitute less of an imposition on free expression.

The Broadcasting Standards Authority has noted that an apology will only be ordered in rare and exceptional circumstances, but makes a distinction between an order to publish an apology and an order to publish a general statement summarising the BSA's decision; ${ }^{287}$ a general statement is considered less serious. An apology seems more like forced speech than a reply does because, with a reply, a defendant can make it clear that he does not personally endorse the reply without undermining it, whereas

\footnotetext{
${ }^{282}$ Cabinet Social Policy Committee, above n 4, at [55.1]-[55.10].

${ }^{283}$ At [55.1]-[55.10].

${ }^{284}$ At $[55.1]-[55.10]$.

285 At [55.1]-[55.10].

${ }^{286}$ Gounalakis, above n 13, at 73.

287 Ashurst and Others and Television New Zealand Ltd - 2010-001, 6 July 2010, at [91]. See also: Hales and Television New Zealand Ltd - 2007-080, 26 May 2008, at [116]. See also: Cotsilinis and Others and Television New Zealand Ltd - 2009-069, 20 October 2009, at [129].
} 
he cannot do that with an apology. An apology requires admission of wrongdoing. ${ }^{288}$ An apology therefore contravenes the self-fulfilment rationale more than a reply might. The other remedies under the new regime that could be used to protect reputation therefore potentially infringe freedom of expression more than a right of reply does.

However, it is important to note that there may be cases where an individual has the resources to post their own reply in response to a damaging statement that will have just as much effect on their reputation as a Court-ordered right of reply. The Commission has suggested that a claimant will only be granted redress if selfregulatory systems and tools on the Internet have been ineffective in redressing any harm caused by an original statement. ${ }^{289}$ So, for example, if the statement complained about was a comment on a news page, a comment submitted by the claimant may be all that is necessary to remedy the harm done. In such cases, a Court-ordered right of reply may be more than is reasonably necessary to achieve its purpose of protecting a claimant's reputation. Moreover, a right of reply may not be as sufficient as a takedown in some circumstances, for example, where a damaging picture has been issued, a reply may not measure up to the harm caused by the photos. It will be important for the courts to consider how much each remedy protects reputation in each circumstance and balance that against the harms caused.

\section{Conclusion on minimal impairment}

If a right of reply conforms to the model prescribed in this section, it will infringe freedom of expression less than the other remedies provided under the new regime that could protect reputation, namely a takedown order, apology, or correction. This makes a right of reply a means of protecting reputation that impinges on freedom of expression no more than is reasonably necessary, thereby satisfying this limb of the Hansen test, so long as a right of reply will actually protect reputation in the particular case being considered, and a self-administered reply would be ineffective.

\footnotetext{
${ }^{288}$ Danziger, above n 102, at 196.

${ }^{289}$ Law Commission, above n 1, at [1.39].
} 
This last limb of the balancing test considers a general question of proportionality and whether the objective benefits society in ways that outweigh the harm done to an individual right or freedom. ${ }^{290}$ A Court should weigh up the benefits of a right of reply against the harms it might cause to free speech and consider which is more within the general public interest. ${ }^{291}$ The Court should give consideration to the value of speech involved, by considering the free speech rationales that are implicated by that speech; the more valuable the speech, the more justification needed for impinging on it. ${ }^{292}$ More value should be given to political speech and speech in the public interest. $^{293}$

\section{How a right of reply advances freedom of expression rationales}

Unlike a takedown, correction, or censoring of speech, right of reply does not pose an absolute limit on freedom of expression rationales, because it does not restrict or remove the original statement. In some circumstances, a right of reply can actually advance listeners', and thus the public's, interests free speech interests.

There is some debate as to whether unbridled discourse actually leads to the discovery of truth. ${ }^{294}$ It is naïve to assume everyone enjoys equal access to the marketplace of ideas. For whatever reason, some views are widely circulated by the media, while others are largely ignored. ${ }^{295}$ Arguably, some restrictions may be needed to prevent false propositions from driving out truths. ${ }^{296}$ A right of reply could help protect these imbalances and advance the marketplace of truth. Consider an instance where a prominent blogger is perpetuating a false story about an individual. A right of reply could counter this story with an equally accessible and featured response, contributing more information to the marketplace and dealing with the issue of unequal access to the marketplace. On the other hand, where a claimant has their own platform from

\footnotetext{
${ }^{290} R v$ Hansen, above $\mathrm{n} 122$, at [132] as per Tipping $\mathrm{J}$.

${ }^{291}$ Ministry of Transport $v$ Noort, above n 76, at 283-284 per Richardson J.

${ }^{292}$ Geiringer and Price, above n 76, at 320-323.

${ }^{293}$ At 322. See also: Lange v Atkinson and Australian Consolidated Press New Zealand Ltd, above $\mathrm{n}$ 14 , at 46.

${ }^{294}$ Greenawalt, above n 88, at 132.

${ }^{295}$ Barendt, above n 86, at 12.

${ }^{296}$ At 9.
} 
which to air their side of the story, and that platform is of equal prominence to the platform for the damaging material, then there will be less justification for a Courtordered right of reply from a marketplace perspective. For example, if a damaging statement is made on Facebook, a claimant will often have the option of replying to the statement directly or on his own Facebook page, and a Court-ordered right of reply may therefore be unnecessary.

A right of reply allows both the defendant and the claimant to fulfil themselves through expression, and has the potential to treat both sides with equal respect and dignity, which accords with the self-fulfilment rationale of free speech. An argument for the restriction of speech under the self-fulfilment rationale is that the government must protect its citizens from harm; not all citizens act in a rational and autonomous manner and some ideas can lead irrational people to act in harmful ways. ${ }^{297}$ Moreover, rational autonomous beings are capable of acting immorally and selfishly in the face of all available information. ${ }^{298}$ A right of reply may not fully guard against irrational actors, or rational actors who choose to act in a harmful way, but it may prevent some irrational action by presenting another side to the story and providing context. For example, consider a situation where a person's angry ex-boyfriend publicised details about her HIV-positive status on his blog, a fact she had been keeping secret from her friends and family due to shame and uncertainty has to her prognosis. HIV and AIDS are stigmatised conditions associated with promiscuity and unsafe and depraved sexual habits. ${ }^{299}$ A reader might take that information, plus the fact that she had been keeping her diagnosis a secret, and harshly judge her as a bad or immoral person. The discovery of those bare facts by a prospective employer conducting a standard Google search on her as a prospective employee might persuade them not to hire her. However, if the courts were to allow the claimant to explain why she kept her diagnosis a secret (maybe she was worried a lot of her friends would abandon her), a reader might judge her less harshly.

As discussed above, the argument from democracy embodies both the marketplace and self-fulfilment rationales of free speech; so one could also argue that by

\footnotetext{
297 Greenawalt, above n 88, at 151.

${ }^{298}$ At 151.

${ }^{299}$ Moji Anderson et all "HIV/AIDS-related stigma and discrimination: Accounts of HIV-positive Caribbean people in the United Kingdom" (2008) 67 Soc Sci Rev 790 at 791.
} 
advancing those rationales, a right of reply also advances the rationale of participation in democracy by fostering the development of ideal democratic participants.

\section{The value of speech}

The more a statement fits within the rationales that underlie free speech, the more value it has, and the more protection it deserves in the face of limitation. ${ }^{300}$ However, the rationales do not attract equal weight. Tipping $\mathrm{J}$ has argued that the rationales of democracy and truth are the more important values of free speech, whilst selffulfilment may be easier to trade off in favour of another right, ${ }^{301}$ and the United States Supreme Court has identified the importance of protecting the right to criticise the government as the central meaning of free speech. ${ }^{302}$ This paper agrees that political speech should be given the most weight.

Nothing in the theory of self-fulfilment or the search for truth explains why freedom of expression is more valuable than other values affecting dignity. ${ }^{303}$ Thus, the outcome of any balancing exercise concerning an expression's contribution to selffulfilment or the marketplace of ideas might rest on the potential harm of that expression as well as its objective value to the public interest. For example, there is more value in knowing the truth about a political figure than there is about the average ordinary person. ${ }^{304}$ The public will also be more interested in verifiable information, because there is little interest in blatantly false speech, especially where it is misleading.

There is even debate about whether truth can be objectively measured. ${ }^{305}$ Mill's theory seems to define truth as that which is the product of open debate; free speech is justified because its process leads to knowledge, but knowledge is defined by that

\footnotetext{
${ }^{300}$ Geiringer and Price, above n 76, at 320-323.

${ }^{301}$ Hosking $v$ Runting, above $\mathrm{n} 83$, at [233]-[235] per Tipping J.

302 David A. Strauss "Freedom of Speech and the Common Law Constitution" in Lee C. Bollinger and Geoffrey R Stone (eds) Eternally Vigilant: Free Speech in the Modern Era (University of Chicago Press, Chicago, 2002) at 36.

${ }^{303}$ Schauer, above n 106, at 25 and 58.

${ }^{304}$ At at 175.

${ }^{305}$ Grant Huscroft "Freedom of Expression" in Grant Huscroft, Scott Optican, Richard Mahoney and Paul Rishworth (eds) The New Zealand Bill of Rights Act 1990 (Oxford University Press, Melbourne, 2003) at 309.
} 
very process. ${ }^{306}$ There is nothing in Mill's theory to suggest an inherent characteristic of "truth" that would be universally recognisable by the general public. ${ }^{307}$ Certainly, there are many historical examples where falsity has prevailed, though one could argue that in many cases truth has won out in the end, albeit after a long period of time. ${ }^{308}$ Nonetheless, allowing the free expression of contrary ideas may be the only way to challenge and modify erroneous beliefs, even if it fails to do so all of the time. ${ }^{309}$

The argument from democracy not only embodies the other two rationales for free speech, positing that they contribute to the development of ideal democratic participants, but also conceptualises free speech as a check on government power. ${ }^{310}$ This makes it a more persuasive argument for protecting speech, and political speech clearly falls within this objective. Therefore, political speech should be considered the most valuable speech. Value will then be given according to how well speech falls within the rationales, so speech that is only considered self-fulfilling will be considered less valuable in comparison to speech that also contributes to the marketplace of ideas. The public interest in the speech, according to how they fit into these rationales, will also be an important consideration. The public interest in protecting the type of speech in a particular case will then be weighed up against the public interest in the benefits a right of reply might provide claimants' reputations.

\section{Applying the proportionality limb}

Whether or not the benefits of a right of reply are overall proportional to the limits imposed on free speech will depend on the nature of the speech in question. For example, where an original statement is an opinion piece about a politician's stance on a government's recent policy decision, the value of that statement will be quite high in accordance with the implicated rationales of free speech. An opinion invokes the self-fulfilment rationale more than a statement of fact, and political opinions contribute to the marketplace of ideas in order to come to the "truth" about political

\footnotetext{
306 Schauer, above n 106, at 22.

307 At 26.

${ }^{308}$ At 26-27.

${ }^{309}$ At 25.

${ }^{310}$ At $43-44$.
} 
policies and philosophies. The ability to develop and air political opinions helps mould individuals into ideal democratic participants and helps to act as a check on the government. Any obligation to publish a reply to such a statement might harm an individual's sense of autonomy and could promote bias, and come across as governmental regulation, of the marketplace of ideas. This would undermine the effect of the original statement as a check on government power. Moreover, regulation could also lead to the chilling of similar statements in the future, stifling the marketplace. By inhibiting self-fulfilment and stifling the marketplace of political ideas and opinions, a right of reply could also inhibit personal political development, leading to fewer consummate democratic participants within society. The harm caused to a politician's reputation may be minimal. Indeed, the opinion's effect on the marketplace of ideas may be to surface the truth about the politician, which would weigh heavily in the public interest. In such cases, the public might be more interested in protecting this sort of speech than the individual reputation of a political official. Moreover, a political official may have his own medium through which to air his reply, making a Court-ordered reply unnecessary. A Court might therefore consider a right of reply to be a disproportionate remedy in light of the harms it might impose on free expression.

Whereas, a false statement about a person's masochistic sex life may be considered low value speech, ${ }^{311}$ because it doesn't fit well within any of the free speech rationales, and would severely harm a claimant's reputation by preventing them from being fairly judged and included within society as a person deserving of human dignity. In such circumstances, the limit of a right of reply on the defendant's free speech will be justified, because the interests in protecting the innocent claimant's reputation outweigh the low value speech; the harm caused by the speech is disproportionate to its value.

\section{Conclusion}

The Commission has sought to address the harms of an unregulated Internet by providing claimants with a right of reply to harmful digital communications. This

${ }^{311}$ Geiringer and Price, above n 76, at 321-322. 
paper suggests that a right of reply can suitably redress statements, of fact or opinion, which have damaged a claimant's reputation in an online context, whether or not they have been made by a member of the "media". A test for whether a statement damages reputation could be whether it impacts their reputation in such a way that they are prevented from being accurately and fairly judged and included within society as people deserving of equal respect and human dignity, or makes right-thinking members of society think less of them. A right of reply infringes free speech by contravening a speaker's right to self-fulfillment and negatively impacting the search for truth and the functioning of democracy for both speakers and listeners. ${ }^{312}$ However, protecting reputation is also an important objective, and a right of reply can advance this objective by providing context or correcting statements that negatively impact an individual's reputation. It is therefore necessary to balance the benefits of a right of reply against the harms it may cause to free speech.

A right of reply should not be ordered where a claimant could post a reply of their own accord that will have a similar effect on their reputation as a Court-ordered right of reply. It should be available in commercial contexts and should apply to websites that are considered "private", as well as those that are clearly in the public domain. However, fair and accurate reports of Parliamentary proceedings should be exempt. A reply should copy the form and placement of the original statement and be made available as long as the original statement is. Whether or not a defendant intended to harm the claimant's reputation should not be a relevant consideration, and there should be no time limits on when a claimant can ask for a reply. A reply should be legal and Court-approved, and any costs are to be borne by the defendant. If a right of reply conforms to this model, the other remedies available for protection of reputation under the new regime will infringe free speech just as much, if not more, making a right of reply a reasonably necessary impairment on free speech. However, whether or not a right of reply is actually proportional to the harms caused to free speech, and therefore demonstrably justified, will depend on the nature of the speech used in the original statement. The courts must then consider, on a case-by-case basis, whether it is more within the public interest to protect a claimant's reputation or to protect the type of speech used in the original harmful digital communication.

${ }^{312}$ Royal, above n 103, at 211-212. 


\section{Bibliography}

$$
\text { A Cases }
$$

$1 \quad$ New Zealand

Lange v Atkinson and Australian Consolidated Press NZ Ltd [1997] 2 NZLR 22 (HC)

Television New Zealand Ltd v Quinn [1996] 3 NZLR 24 (CA)

Moonen v Film and Literature Board of Review [2000] 2 NZLR 9 (CA)

Thompson v Police [2013] 1 NZLR 848

Brooker v Police [2007] 3 NZLR 91 (SC)

Hosking v Runting [2005] 1 NZLR 1 (CA)

Morse v R [2010] 2 NZLR 625 (CA)

Hopkinson v Police [2004] 3 NZLR 704 (HC)

$R v$ Hansen [2007] NZSC 7, [2007] 3 NZLR 1

Ministry of Health $v$ Atkinson [2012] 3 NZLR 456 (CA)

Mount Cook Group Ltd v Johnstone Motors Ltd [1990] 2 NZLR 488 (HC)

The Christchurch Press Company Ltd v McGaveston Hilton Roger (13 December 1985) CA191/84

Radio NZ v Ellis (2005) CIV 2004-485-2035 (HC)

Mitchell v Sprott [2002] 1 NZLR 766 (CA)

Ministry of Transport $v$ Noort [1992] 3 NZLR 260 (CA)

2 Canada

Slaight Communications Inc v Davidson (1989) 59 DLR (4th) 416

\section{United States}

West Virginia State Board of Education v. Barnette, 319 US 624 (1943)

Riley $v$ National Federation of the Blind 487 US 781(1988) 
Miami Herald Publishing Co. v. Tornillo, 418 US 241 (1974)

4 England

Reynolds v Times Newspapers Ltd [2001] 2 AC 127 (HL)

Sim v Stretch [1936] 2 All ER 1237 (HL)

Joseph v Spiller [2010] UKSC 53, [2011] 1 AC 852

\section{$5 \quad$ Hong Kong}

Tse Wai Chun v Cheng [2001] EMLR 777

6 New Zealand Broadcasting Standards Authority Decisions

Anderson and Others and Cruise FM Waikato - 2012-133, 25 July 2013

Ashurst and Others and Television New Zealand Ltd - 2010-001, 6 July 2010.

Hales and Television New Zealand Ltd - 2007-080, 26 May 2008

Cotsilinis and Others and Television New Zealand Ltd - 2009-069, 20 October 2009

\section{$B \quad$ Statutes}

$1 \quad$ New Zealand

Defamation Act 1992

New Zealand Bill of Rights Act 1990

Broadcasting Act 1989

Defamation Act 1954

\section{Germany}

Civil Code in the version promulgated on 2 January 2002 (Federal Law Gazette [Bundesgesetzblatt] I page 42, 2909; 2003 I page 738), last amended by Article 1 of the statute of 27 July 2011 (Federal Law Gazette I page 1600)

$<$ http://www.gesetze-im-internet.de/englisch_bgb/englisch_bgb.html $>$ 


\section{International Materials}

Proposal for a Recommendation of the European Parliament and of the Council on the protection of minors and human dignity and on the right of reply in relation to the competitiveness of the European audiovisual and online information services industry, 7064/06 (March 2006)

International Covenant on Civil and Political Rights, 999 UNTS 171 (signed 16 December 1966, entered into force 23 March 1976)

European Convention for the Protection of Human Rights and Fundamental Freedoms, as amended by Protocols Nos 11 and 14, 5 ETS (4 November 1950)

\section{Law Commission Publications}

Law Commission Harmful Digital Communications: The Adequacy of Current Sanctions and Remedies (NZLC Ministerial Briefing Paper, 2012)

Law Commission The News Media Meets 'New Media': Rights, Responsibilities and Regulation in the Digital Age (NZLC R128, 2013)

Law Commission The News Media Meets 'New Media': Rights, Responsibilities and Regulation in the Digital Age (NZLC IP27, 2011)

\section{E Parliamentary Materials}

Cabinet Social Policy Committee Harmful Digital Communications: Cabinet Social Policy Committee Paper <http://www.justice.govt.nz/publications/globalpublications/h/harmful-digital-communications-cabinet-social-policycommittee-paper/publication>

Judith Collins and Craig Foss "Government responds to news media report" (12 September 2013) beehive.govt.nz <http://beehive.govt.nz/release/governmentresponds-news-mediareport?utm_source $=$ feedburner\&utm_medium $=$ email\&utm_campaign $=F e e d \% 3 \mathrm{~A}+$ bee hive-govt-nz $\% 2$ Fportfolio $\% 2$ Fjustice $+\% 28$ Justice+-+beehive.govt.nz $\% 29>$

$$
\text { F Books }
$$

Tracey Walker Reputation Matters: A Practical Legal Guide to Managing Reputational Risk (CCH New Zealand Limited, Auckland, 2012)

Georgios Gounalakis Privacy and the Media: A Comparative Perspective (Verlag $\mathrm{CH}$ Beck, Munchen, 2000)

Lawrence McNamara Defamation and Reputation (Oxford University Press, New York, 2007) 
Huw Beverley-Smith, Ansgar Ohly and Agnes Lucas-Schloetter Privacy, Property and Personality: Civil Law Perspectives on Commercial Appropriation (Cambridge University Press, New York, 2005)

Dan Jerker B Svantesson Private International Law and The Internet (Kluwer Law International BV, The Netherlands, 2007)

Graham J H Smith and Bird and Bird Internet Law and Regulation (4th ed, Sweet \& Maxwell, London, 2007)

Richard McChesney Rich Media, Poor Democracy: Communications Politics in Dubious Times (University of Illinois Press, Illinois, 1999)

Claudia Geiringer and Steven Price "Moving From Self-Justification to Demonstrable Justification - the Bill of Rights and the Broadcasting Standards Authority" in Jeremy Finn and Steven Todd (eds) Law, Liberty, Legislation: Essays in Honour of John Butler QC (LexisNexis NZ, Wellington, 2008)

Vincent Blasi "Free Speech and Good Character: From Milton to Brandeis to the Present" in Lee C. Bollinger and Geoffrey R Stone (eds) Eternally Vigilant: Free Speech in the Modern Era (University of Chicago Press, Chicago, 2002)

Eric Barendt Freedom of Speech ( $2^{\text {nd }}$ ed, Oxford University Press, New York, 2005)

Frederick Schauer Free Speech: a philosophical enquiry (Cambridge University Press, New York, 1982)

Randal Marlin Propaganda and the Ethics of Persuasion (Broadview Press Ltd, Ontario, 2002)

Steven Price Media Minefield (New Zealand Journalists Training Organisation, Wellington, 2007).

Andrew Butler and Petra Butler "Protecting Rights" in Caroline Morris, Jonathan Boston and Petra Butler (eds) Reconstituting the Constitution (Springer, Heidelberg, 2011)

Ursula Cheer and John Burrows "Defamation" in Stephen Todd et all (eds) The Law of Torts in New Zealand (6 ${ }^{\text {th }}$ ed, Brookers, Wellington, 2013)

Daniel J Solove The Future of Reputation: gossip, rumour and privacy on the internet (Yale University Press, London, 2007)

Enid Campbell Parliamentary Privilege (The Federation Press, Sydney, 2003)

John Burrows and Ursula Cheer Media Law in New Zealand (LexisNexis NZ, Wellington, 2010) 
David A. Strauss "Freedom of Speech and the Common Law Constitution" in Lee C. Bollinger and Geoffrey R Stone (eds) Eternally Vigilant: Free Speech in the Modern Era (University of Chicago Press, Chicago, 2002)

Grant Huscroft "Freedom of Expression" in Grant Huscroft, Scott Optican, Richard Mahoney and Paul Rishworth (eds) The New Zealand Bill of Rights Act 1990 (Oxford University Press, Melbourne, 2003)

Geoffrey Palmer "The Law of Defamation in New Zealand - Its Recent Evolution and Problems" in Jeremy Finn and Steven Todd (eds) Law, Liberty, Legislation: Essays in Honour of John Butler QC (LexisNexis NZ, Wellington, 2008)

\section{G Journal Articles}

Richard C Donnelly "A Right of Reply: An Alternative to an Action for Libel” (1948) 34 Va Law Rev 867

Kyu Ho Youm "The Right of Reply and Freedom of the Press: An International and Comparative Perspective" (2008) 76 Geo Wash L Rev 1017

Mike Wagner "Privacy and Reputaiton in the Internet Age" (2013) 71 Advocate 347

Ruth Rettie "Net Generation Culture" (2002) 3 JECR 254

Daniel W Drezner "The Global Governance of the Internet: Bringing the State Back In" (2004) 119 Polit Sci Q 477

Erik P Lewis, “Unmasking 'Anon12345': applying an appropriate standard when private citizens seek the identity of anonymous internet defamation defendants" (2009) 2009 U Ill L Rev 947

Jerome A Barron "Rights of Access and Reply to the Media in the United States Today" (2003) 25 Comm \& L 1

Susana N Vittadini Andres "First Amendment influence in argentine republic law and jurisprudence" (1999) 4 Comm L \& Pol'y 149

Jerome A Barron “Access to the Media - A Contemporary Appraisal” (2006) 35 Hofstra L Rev 937

Laurie Allen Gallancy "Teachers and the Pledge of Allegiance" (1990) 57 U Chic L Rev 929

Kent Greenawalt "Free Speech Justifications” (1989) 89 Colum L Rev 119

Andras Koltay “The Right of Reply: A Comparative Approach” (2007) 4 Iustum Aequum Salutare 203

Larry Alexander “Compelled Speech” (2006) 23 Const Comment 147 
Charles Danziger "The Right of Reply in the United States and Europe" (1986-1987) 19 NYU J Int'l L \& Pol 171

Dayna B Royal "Resolving the Compelled-Commercial-Speech Conundrum" (2011) 19 Va J Soc Pol'y \& L 205

Juliet Moses "Hate Speech: Competing Rights to Freedom of Expression" (1996) 8 Auckland U L Rev 185

Robert C Post "The Social Foundations of Defamation Law: Reputation and the Constitution" (1986) 74 Cal Rev 691

A O Ferrers "The law is right to value reputation more than life or limb" (1990) 4 NZLJ 152

Robert N Bellah “The Meaning of Reputation in American Society” (1986) 74 Cal L Rev 743

Francis Fukuyama "Differing Disciplinary Perspectives on the Origins of Trust" (2001) 81 B U L Rev 479

Helen Nissenbaum “Securing Trust Online: Wisdom or Oxymoron?" (2001) 81 B U L Rev 635

Herbert W Titus "Statement of Fact Versus Statement of Opinion - A Spurious Dispute in Fair Comment" (1961-1962) 15 V \& L Rev 1203

Fredrick Schauer "Language, Truth and the First Amendment: An Essay in Memory of Henry Canter" (1978) 64 Va Law Rev 263

Jerry J Phillips “Opinion and Defamation: The Camel in the Tent" (1989-1990) 57 Ten L Rev 647

Rodney W Ott "Fact and Opinion in Defamation: Recognizing the Formative Power of Context" (1990) 58 Fordham Law Rev 761

Moji Anderson et all "HIV/AIDS-related stigma and discrimination: Accounts of HIV-positive Caribbean people in the United Kingdom” (2008) 67 Soc Sci Med 790

Stijn Smet "Freedom of Expression and the Right to Reputation: Human Rights in Conflict” (2010) 26 Am U Int'l L Rev 183

Joan E Schaffner "Protection of Reputation versus Freedom of Expression: Striking a Manageable Compromise in the Tort of Defamation" (1989-1990) 63 S Cal L Rev 433

Dan Jerker B Svantesson "The Right of Reputation in the Internet Era" (2009) 23 IRLCT 169 
Richard H Stein 'Freedom of the Press vs. The Public's Right to Know: Newspaper Right of Reply Statutes" (1974) 43 U Cin L Rev 164

Stephen Gardbaum "A Reply to the Right of Reply" (2007-2008) 76 Geo Wash L Rev 1066

Andrew Geddis "The State of Freedom of Expression in New Zealand: an admittedly eclectic overview" (2005-2008) 11 Otago L Rev 657

Michael D Scott "Would a 'right of reply' fix Section 230 of the Communications Decency Act?” (2012) 20 Int'l JL \& Info Tech 73

\section{H Internet Materials}

Eduard Kovaks "Anonymous Hackers Plan Anti-Facebook Censorship Protest for April 6" (26 March 2013) Softpedia <http://news.softpedia.com/news/AnonymousHackers-Plan-Anti-Facebook-Censorship-Protest-for-April-6-340389.shtml>

Emma Woolacott "As Pirate Bay Launches Anti-Censorship Browser, Has It Lost Its Way?" (12 August 2013) Forbes

$<$ http://www.forbes.com/sites/emmawoollacott/2013/08/12/as-pirate-bay-launchesanti-censorship-browser-has-it-lost-its-way/>

EDRI-gram French Draft Decree Regarding The Right To Reply On The Internet (28 March 2007) EDRI-gram <http://www.edri.org/edrigram/number5.6/right-to-replyfrance>

Georges Rouhette and Anne Rouhette-Berton "English Translation of the French Civil Code" (4 April 2006) Legifrance

$<$ http://www.legifrance.gouv.fr/Traductions/en-English/Legifrance-translations>

Inter Nationes "English Translation of Basic Law for the Federal Republic of

Germany (Grundgesetz, GG)" IUSCOMP

$<$ http://www.iuscomp.org/gla/statutes/GG.htm\#2>

Raymond Young "Marlene Dietrich Case BGH 1 ZR 49/97 (1 December 1999)" (1

December 2005) The University of Texas: School of Law

$<$ http://www.utexas.edu/law/academics/centers/transnational/work_new/german/case. php?id=726>

Maximilian Ruhenstroth-Bauer "The right of reply in Germany" (13 February 2012) Free Speech Debate < http://freespeechdebate.com/en/case/the-right-of-reply-ingermany/>

Supreme Court of Korea "Supreme Court Decision [Press Report Correction] Da86782 (November 15 2011)" Supreme Court of Korea $<$ http://library.scourt.go.kr/jsp/html/decision/9-64\%202012.11.15.2011Da86782.htm> 
Mike Deri Smith "Fake Reviews Plague Consumer Websites" (26 January 2013) The Guardian < http://www.news.com.au/technology/public-asked-to-help-withcrackdown-on-fake-online-testimonials-and-the-removal-of-negative-reviews/storye6frfro0-1226625385230>

Drew “Stop Stealing my Sh*t!” Skinny Artist $<$ http://skinnyartist.com/stop-stealingmy-images/>

Leah Parsons "A Company Stole a Picture of My Daughter Rehtaeh Parsons, Who Committed Suicide After Rape, and Used it on a Dating Ad on Facebook" (18 September 2013) xoJane: It Happened to Me < http://www.xojane.com/it-happenedto-me/rehtaeh-parsons-facebook-dating-ad $>$

Justin Lafferty "STUDY: Confusing Facebook Privacy Settings Lead To More Public Information" (6 March 2013) AllFacebook: The Unofficial Facebook Blog < http://allfacebook.com/carnegie-mellon-facebook-privacy-study_b112298>

\section{Research Papers}

Jessica Medberry "Censorship and Adolescent Literature" (Senior Honors Thesis, Colorado State University, 15 December 2009)

Judit Bayer "Liability of ISPs for Third Party Content" (Senior Research Fellow Paper, Victoria University of Wellington, 2006)

Ralph Gross and Alessandro Acquisti "Information Revelation and Privacy in Online Networks (The Facebook Case)" (paper presented at ACM Workshop on Privacy in the Electronic Society (WPES), Alexandria, Virginia, November 2005)

Paul Rishworth "How to Interpret and Apply the Bill of Rights" (paper presented to the New Zealand Law Society The Bill of Rights - Getting the Basics Right Seminar, November 2001)

Molly Woods “Don't Be Evil: Mantra or Mask? An analysis of Google's liability for online defamation" (Honours Thesis, Victoria University of Wellington, 2012)

Grace Liang "Should We Shoot the Messenger? The New Zealand Direction on the Liability of Internet Service Providers for Third Party Defamation" (Honours Thesis, Victoria University of Wellington, 2012) 